\title{
Potential Biomarkers for Diagnosis and Screening of Autism Spectrum Disorders
}

\author{
Anna Meiliana ${ }^{1,2, *}$, Andi Wijaya ${ }^{2,3}$ \\ ${ }^{1}$ Postgraduate Program in Clinical Pharmacy, Padjadjaran University, Jl. Eijkman No.38, Bandung, Indonesia \\ ${ }^{2}$ Prodia Clinical Laboratory, Jl. Cisangkuy No.2, Bandung, Indonesia \\ ${ }^{3}$ Postgraduate Program in Clinical Biochemistry, Hasanuddin University, Jl. Perintis Kemerdekaan Km.10, Makassar, Indonesia \\ ${ }^{*}$ Corresponding author. E-mail: anna.meiliana@prodia.co.id
}

\section{Abstract}

$\mathrm{B}$ ACKGROUND: Autism spectrum disorder (ASD) is a highly heritable neurodevelopmental condition, which is typically characterized by a triad of symptoms: impaired social communication, social reciprocity and repetitive stereotypic behavior. While the behavioral phenotype of ASD is well described, the search for reliable 'autism biomarkers' continues.

CONTENT: Insulin growth factor (IGF) is essential for the myelination of developing fetal neurons; this is in addition to the well-known links between IGF, maternal inflammation, infection and autism supporting IGF as a potential marker. Combining IGF data with data regarding levels of the known markers, serotonin and anti-myelin basic protein, in order to calculate an autism index, could provide a new diagnostic method for at-risk neonates. Disruptions to multiple pathophysiological systems, including redox, folate, methylation, tryptophan metabolism, and mitochondrial metabolism, have been well documented in autistic patients. Maternal infection and inflammation have known links with autism. Autoimmunity has therefore been a well-studied area of autism research. The potential of using autoantibodies as novel biomarkers for autism, in addition to providing insights into the neurodevelopmental processes that lead to autism.

SUMMARY: The six proposed causes of autism involve both metabolic and immunologic dysfunctions and include: increased oxidative stress; decreased methionine metabolism and trans-sulfuration: aberrant free and bound metal burden; gastrointestinal (GI) disturbances; immune/inflammation dysregulation; and autoimmune targeting. A newborn
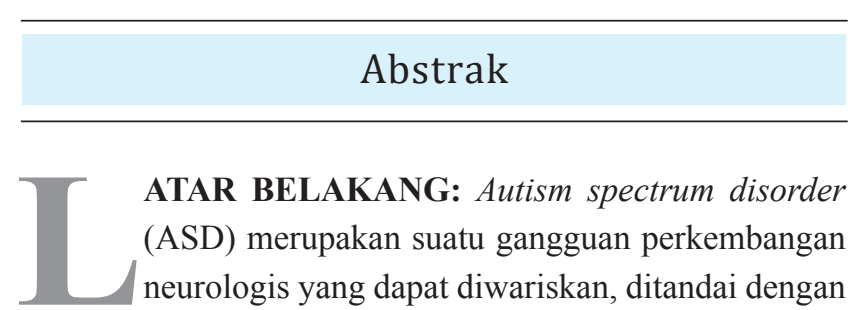

ATAR BELAKANG: Autism spectrum disorder (ASD) merupakan suatu gangguan perkembangan neurologis yang dapat diwariskan, ditandai dengan tiga ciri: gangguan komunikasi sosial, gangguan interaksi timbal balik, dan perilaku khas berulang. Walaupun fenotipe perilaku ASD telah banyak dijelaskan, akan tetapi biomarker autisme yang dapat diandalkan masih dicari.

ISI: Selain berperan penting untuk pembentukan myelin pada neuron fetus, insulin growth factor (IGF) diketahui memiliki kaitan dengan inflamasi maternal, infeksi, dan autisme, sehingga IGF merupakan marker yang potensial. Kombinasi data IGF dengan data marker lain yang diketahui, seperti serotonin dan anti-myelin basic protein, dapat digunakan untuk menghitung indeks autisme, sehingga dapat menjadi metode diagnostik baru untuk bayi baru lahir yang berisiko. Gangguan pada berbagai sistem patofisiologi, termasuk redoks, folat, metilasi, metabolisme triptofan, dan metabolisme mitokondria, telah terdokumentasi pada pasien autisme. Infeksi dan inflamasi maternal diketahui memiliki hubungan dengan autisme. Autoimunitas juga sudah banyak diteliti pada autisme. Autoantibodi memiliki potensi sebagai biomarker baru untuk autisme, selain itu dapat pula memberikan pengetahuan mengenai proses perkembangan saraf yang mengarah kepada autisme.

RINGKASAN: Enam penyebab autisme yang telah dikemukakan, melibatkan baik disfungsi metabolisme maupun imunologi, meliputi: peningkatan stress oksidatif; penurunan metabolisme metionin dan transsulfurasi; kadar logam bebas dan terikat yang berlebih; gangguan gastrointestinal; disregulasi imunitas/inflamasi; 
screening program for early-onset ASD should be capable of utilizing a combination of ASD-associated biomarkers representative of the six proposed causes of autism in order to identify newborns at risk. The biomarkers discussed in this article are useful to guide the selection, efficacy, and sufficiency of biomedical interventions, which would likely include nutritional supplementation, dietary changes, and specific medications for treating GI pathogens and reducing inflammation.

KEYWORDS: ASD, autism, biomarkers, newborn screening, diagnosis

Indones Biomed J. 2014; 6(3): 137-56 dan timbulnya autoimun. Program skrining pada bayi baru lahir untuk onset awal ASD dapat dilakukan dengan memanfaatkan kombinasi biomarker yang merepresentasikan keenam penyebab autisme tersebut. Biomarker yang dibahas pada artikel ini bermanfaat sebagai panduan untuk pemilihan intervensi biomedis yang cukup efektif, meliputi suplementasi nutrisi, perubahan diet, dan pengobatan untuk menatalaksana patogen gangguan pencernaan dan mengurangi inflamasi.

KATA KUNCI: ASD, autisme, biomarker, skrining bayi baru lahir, diagnosa

\section{Introduction}

Autism is a neurodevelopmental disorder characterized by impaired communication and social interaction and repetitive behaviors. Several lines of evidence indicate that genetic, environmental, and immunological factors may play a role in its pathogenesis.(1) Some investigators expand the nature of autism to that of a multisystem metabolic disease, not just a brain disorder.(2) The term autistic spectrum disorder (ASD) or pervasive developmental disorders (PDDs) represents a group of disorders which includes five diagnostic subtypes including autism, PDD not otherwise specified (PDD-NOS), Rett's disorder, child disintegrative disorder, and Asperger's disorder.(3)

The incidence of autism is now 1 per 110 in the United States, and 1 per 64 in the United Kingdom, with similar incidences throughout the world. The gender ratio is 3-4 boys : 1 girl.(4) Autism is a lifelong condition for most. Historically, $75 \%$ of autistic individuals become either institutionalized as adults or are unable to live independently.(5) Studies of adults with autism suggest that the cumulative mortality rate is higher among autistic patients than their non-autistic peers.(6)

Since there are no objective diagnostic tests for autism, a clinical diagnosis is based on behavior, using the Diagnostic and Statistical Manual of Mental Disorders, Fourth Edition, Text Revision (DSM-IV, TR) as the gold standard. Using a list of diagnostic criteria, at least six criteria must be exhibited with onset of conditions prior to age three, including at least two relating to social abnormalities and one each regarding impaired communication and range of interests and activities.(7) These criteria are not described in detail, leaving latitude for clinical judgment.(8) To date,

\section{Diagnosis: rising}

By some counts, autism diagnoses have climbed steadily since the 1970 s. Some research has found explanation for more than half of the rise (right).

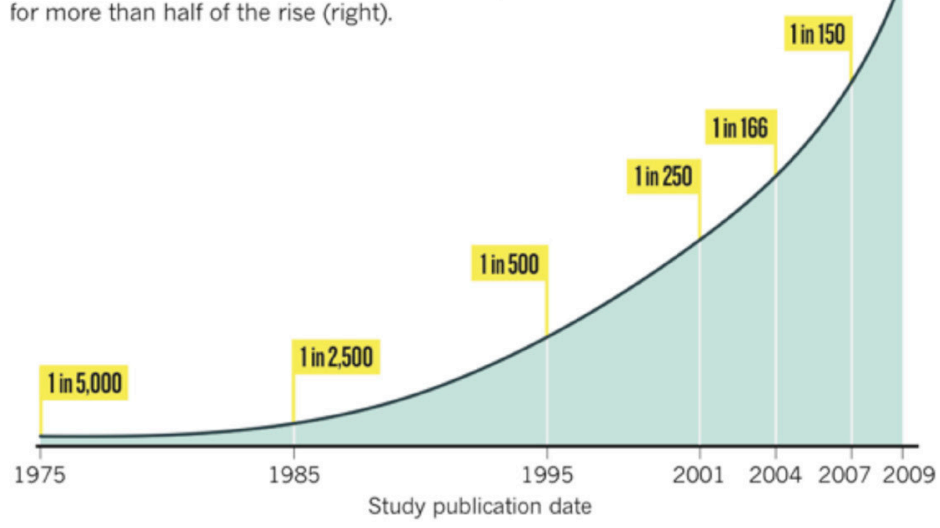

Reasons: unclear

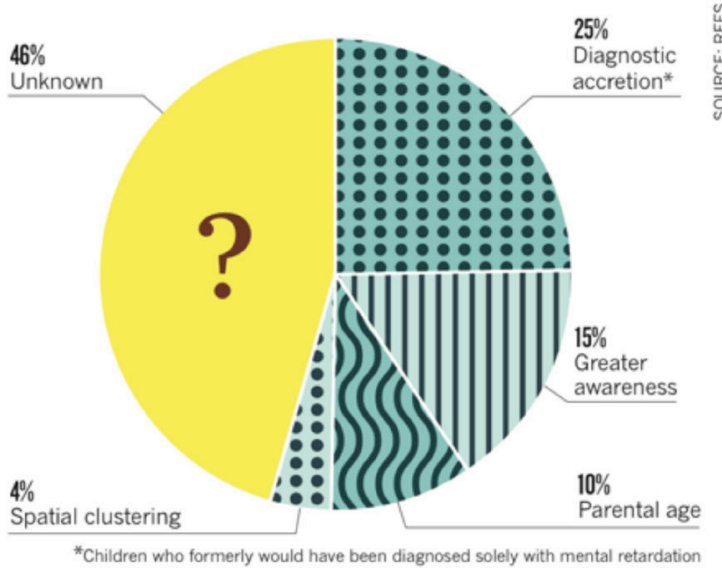

Figure 1. Epidemiologic Study on Autism. (10) (Adapted with permission from Nature Publishing Group). 
no biological markers have been found to reliably diagnose autism in an individual patient.(9)

Therefore, there is a strong need for finding biologically defined autistic phenotypes that can guide further investigations into the biological and genetic underpinnings of ASD. The lack of existing biomarkers is ultimately due to the complexity of the condition, as ASDs are known to have multiple causes, co-morbid conditions, and vary in the type and severity of symptoms expressed by different individuals. Therefore, it is unlikely that ASD can be linked to a single biomarker (i.e., a single gene or brain region). Instead, autism biomarkers are most likely to be multivariate and complex, encompassing data from different aspects of biology as well as genetics.(11)

Therefore, while the search for autism biomarkers is still in its infancy, the availability of new analytical techniques with high exploratory power and predictive value offers promising new ventures into finding a biomarker (or a set of biomarkers) whose complexity equals the etiological complexity of the condition. If successful, such a biomarker may one day prove invaluable in diagnosing, treating and characterizing ASD (11).

\section{ASD}

Autism has increased to epidemic proportions, affecting four times as many males and females. With a prevalence of 1/110 in the United States, 1/64 in the United Kingdom, and similar ratios in many other countries, a very significant threat to future generations is evident.(12)

Autism is a disability that can make daily activities difficult. One out of ten autistics cannot speak, nine out of ten have no regular job, and four out of five autistics adults are still dependent on their parents. Most face the harst consequences of living in a world that has not been constructed around their priorities and interests.(13) Autism is a heterogeneous disorder with multiple causes and courses, a great range in the severity of symptoms, and several associated co-morbid disorders. Increasingly, researchers refer to 'the autisms' rather than a single autism phenotype.(14) It would be surprising, therefore, if the neuropathology of autism was identical across all affected individuals.(15)

As initially described by Kanner (16), individuals with autism have three core features: (i) impairments in reciprocal social interactions; (ii) an abnormal development and use of language; and (iii) repetitive and ritualized behaviors and a narrow range of interests. In addition to the core features of autism, there are common co-morbid neurological disorders.
(17) The prevalence of mental retardation in idiopathic autism is $\sim 60 \%$ although, when the autism spectrum is taken as a whole, the number is closer to $30 \%$.(18) Epilepsy has long been associated with autism although estimates of the occurrence of seizure disorder vary 5-44\%.(19) Anxiety and mood disorders are also very common in autism.(20) There is also substantial heterogeneity in the onset of autism. Some children have signs of developmental delays within the first 18 months of life. However, $25-40 \%$ of children with autism initially demonstrate near normal development until 18-24 months, when they regress into an autism that is generally indistinguishable from early-onset autism.(21) The possibility that there is early-onset versus regressive phenotypes of autism might have important implications for the types and time courses of neuropathology that one might expect to encounter.(15)

The mechanisms that lead to autism are at best poorly understood, however they do center around the disruption of normal cerebral development and its subsequent implications on the functional brain unit (although the exact link to the classic triad of core symptoms remains unascertained). Numerous neuropsychiatry papers attribute the pathogenesis of autism specifically to 'localised' anomalies (i.e. of neural migration or connectivity), which have the potential to detrimentally effect central nervous system (CNS) structure and function.(22-24) The stereotypic behaviors and marked delay or disruption of communication and social behavior trajectories that characterize ASD indicate that crucial neuroanatomic structures and neurodevelopmental pathways may be affected during intra-uterine and/or early postnatal brain development. Several lines of research indicate that ASD are associated with disarrangement of neuronal organization, cortical connectivity and neurotransmitter pathways.(25) While the causes of these abnormalities are still being identified, it is generally believed that genetic as well as environmental factors are involved in the pathogenesis of ASD. $(23,26,27)$

One consistent finding in ASD is altered brain growth, which has been extensively documented by Courchesne et al.(28) The clinical onset of autism appears to be preceded by two phases of brain growth abnormalities: a reduced head size at birth, then a sudden and excessive increase between 1-2 months and 6-14 months of age.(29,30) Furthermore, recent neuroimaging studies have shown an abnormal pattern of brain overgrowth also occurs in areas of the frontal lobe, cerebellum and limbic structures between 2 and 4 years of age, a pattern that is followed by abnormal slowness in brain growth.(28-31) These brain regions are intimately involved in the development of social, communication and motor abilities that are impaired in ASD (25). 
Several studies have proposed that autism might be caused by an imbalance between excitation and inhibition in key neural systems including the cortex.(32) Three main types of defects have been revealed in autism: the brainstem and cerebellum, the limbic system (amygdala and hippocampus), and the cortex.(33-35) Abnormal regulation of brain growth in autism results in early overgrowth followed by abnormally slowed growth.(35) The strongest evidence implicates the glutamatergic and $\gamma$-aminobutyric acid (GABA)ergic and serotonergic systems, with weaker evidence for catecholaminergic, peptidergic, and cholinergic systems.(32) The serotonergic system may be dysregulated in autism; serotonin levels are initially lower than normal but gradually increase to a greater extent than adult levels by $2-15$ years of age.

Autism has been documented to be caused by genetic defects and/or inflammation of the brain. The inflammation could be caused by a wide variety of environmental toxicants, infections, and co-morbidities in individuals genetically prone to the developmental disorder. Some patients with autistic phenotypes clearly have genetic-based primary mitochondrial disease.(36) The lowered cellular energetics and deficient reserve mitochondrial energy capacity could lead to cognitive impairment and language deficits, both common in autistic individuals. It has been determined that autism can be caused by an underlying predisposition to mitochondrial dysfunction.(37) These data support Jepson's assessment that autism is a multi-organ metabolic disease caused by the environment or a virus in individuals who are genetically prone to the disorder. Whatever its cause(s), autism affects critical parts of metabolism, with symptoms in the immunological, gastrointestinal (GI), toxicological, and neurological systems.(38) Therefore, other causes of autism must be considered, such as viral, bacterial, and/or environmental.

In the urgent search to elucidate the etiology of autism, care must be taken to distinguish between correlation and causation. Many hypotheses have been proposed to explain the origin of this disease, but none has been insightful enough to resolve this enigma convincingly. Given this shortcoming, diagnostic medicine is consequently dependent on identifiable biomarkers, most or all of which are comorbid but questionably causative with autism (39).

\section{ASD Risk Factors}

Environmental toxicants exposure has been implicated in a wide variety of disorders (40). Toxicants, such as heavy metals, pesticides and chemicals, can damage cells by converging on similar biochemical pathways to produce adverse effects, such as increasing oxidative stress, depleting glutathione and impairing cellular signaling.(41) Exposures to environmental toxicants, such as mercury $(\mathrm{Hg})$, lead $(\mathrm{Pb})$, arsenic, polychlorinated biphenyls and toluene, are known to cause neurodevelopmental disorders (42), such as attention deficit hyperactivity disorder (ADHD) (43-45), depression (46) and schizophrenia (47) as well as ASD (48$50)$. In considering potential environmental contributors to ASDs, some studies have reported that exposure to $\mathrm{Hg}$ can cause immune, sensory, neurological, motor, and behavioral dysfunctions similar to traits defining or associated with autistic disorders, and that these similarities extend to neuroanatomy, neurotransmitters, and biochemistry.(51-54) Though certain essential trace elements are required in trace amounts for various physiological processes, but at higher concentrations, these micronutrients tend to be toxic and derange various physiological processes, leading thereby to diseases.(55) Similarly, deficiency of essential elements may also lead to significant health concerns.(56) Therefore, it is important to determine the metal concentrations in humans to monitor and assess their impact on health.(55) Recent evidences reveal that many children with autism have multiple medical problems including increase in toxic metal burden.(57)

It is well known that copper $(\mathrm{Cu})$ is one of many metal ions that are required for essential body functions but are toxic in excess quantity.(58) Potential neurotoxic effects of this metal include depression, irritability, nervousness (59), and learning behavioral disorders in children (60). Increased concentration of $\mathrm{Cu}$ in hair and nail is likely to be a valid indication of the body burden. The reported level of zinc $(\mathrm{Zn})$ indicates the $\mathrm{Cu} / \mathrm{Zn}$ imbalance. As $\mathrm{Cu}$ and $\mathrm{Zn}$ are antagonists in function, the reported level of $\mathrm{Zn}$ indicates its insufficiency to excrete excess $\mathrm{Cu}$ which results in $\mathrm{Cu}$ toxicity. Protein intolerance which is observed in autistic children is a result of high $\mathrm{Cu}$ and low Zn.(61) Physically, the $\mathrm{Cu}$ build-up interferes with proper conversion of thyroid hormone at the cellular level. It is very interesting to correlate the report by Adams et al. (62) who have also stated that low iodine levels and abnormal thyroid functions to be the likely contributors of defective speech and cognitive skills in autistic children. Magnesium $(\mathrm{Mg})$ is essential to the body's utilization of vitamin B6 and numerous recent studies have demonstrated that autistic children showed marked improvement when given a large daily supplement of vitamin B6 and Mg.(63) Because of the beneficial 'calming' effect of $\mathrm{Mg}$, symptoms resulting from 
a deficiency in the mineral may include anxiety, depression, hyperactivity (64), agitation, hallucination, irritability, nervousness (59), aggression, chronic stress (65), learning disability, and memory impairment (66). There is also evidence suggesting significant lower level of $\mathrm{Mg}$ in the hair of autistic children when compared to normal controls.(67) There is also evidence showing that children with regressive autism have consistently elevated levels of oxidative stress as compared to normal children. Individuals with $\mathrm{Mg}$ and selenium (Se) deficiency resulting to reduced glutathione antioxidant capacity will be under oxidative stress and will be more vulnerable to toxic compounds that act primarily through oxidative damage.(68)

$\mathrm{Hg}$ is known to accumulate in endocrine organs such as the pituitary gland, thyroid, and hypothalamus and to alter hormone levels and endocrine system development during crucial periods of development.(69) Such effects are usually permanent and affect the individual throughout their life. Some of the documented effects of exposure to toxic metals include significant learning and behavioral disabilities, mental retardation, autism, etc. It is also stated that the incidence of neurological conditions in children such as autism has increased over $200 \%$ in the last decade (70) and $\mathrm{Hg}$ has been found to be a factor in most of those tested.(71) High $\mathrm{Pb}$ levels have been found to be associated with attention deficit hyperactivity disorder, impulsivity, and inability to inhibit inappropriate responding.(72)

There is also evidence offering relationship between the severity of autism and a biomarker related to heavy metal toxicity, which found that elevations in urinary porphyrins (associated with $\mathrm{Hg}$ or $\mathrm{Pb}$ and $\mathrm{Hg}$ toxicity) were significantly associated with Childhood Autism Rating Scale (CARS). The present investigation also supports the evidence by providing data that shows increasing order (low functioning autism (LFA) $>$ medium functioning autism (MFA) $>$ high functioning autism (HFA)) of toxic metals $(\mathrm{Pb}$ and $\mathrm{Hg}$ ) concentration in the hair and nail samples and their correlation with degree of severity. Also, it is notably important that the level of essential trace elements like $\mathrm{Mg}$ and Se are decreased in the order of severity which indicates that the lower the level of $\mathrm{Mg}$ and $\mathrm{Se}$, the higher is the risk of metal burden and severe is the autism (73). The hair and nails in which trace minerals are sequestered and/or stored can be used to effectively monitor the highest priority toxic trace metals (74). Hair and nails are recording filaments that can reflect metabolic changes of many elements over long periods of time. The advantages of hair and nail tissue analysis over other diagnostic samples is that trace metal concentrations are not subjected to rapid fluctuation due to diet, air, and water; hence, there is long-term stability over nutritional status.(75)

There is considerable evidence about the important role of iron on cognitive, behavioral, and motor development. (76) It is a component of many enzymes involved in neurotransmitter synthesis, and in iron deficiency, due to decreased activity of associated enzymes, monoamine neurotransmitter systems may be affected.(77) A decrease in brain iron concentration is accompanied by changes in serotonergic and dopaminergic systems, in cortical fiber conduction, and myelogenesis.(78) Prenatal/maternal factors linked to increased autism risk include valproic acid, thalidomide, alcohol, rubella, cytomegalovirus, depression, schizophrenia, obsessive-compulsive disorder, autoimmune disease, stress, allergic reaction, and hypo-thyroidism. It will be shown how each of these risk factors may initiate expression of genes which are sensitive to retinoic acid (RA) and/or estradiol, whether by direct promotion or by reducing production of alpha-fetoprotein (79). The RA/estradiol theory of autism causation put forth in this paper potentially explains a great deal of observational data regarding the autism spectrum, and links together 12 seemingly unconnected risk factors for autism. The folic acid theory of epidemic causation potentially explains the root cause of increasing autism rates within the framework of the RA/estradiol model, and provides possible explanations for regression in autism and changes over time in autism symptomatology. These hypotheses are unique, in that they assert that autism is a disorder of genetic expression rather than a genetic disorder (79).

Viral infections, such as herpes simplex, rubella, or cytomegalovirus, during pregnancy increase the incidence of juvenile autism.(80) The most common maternal virus during the first trimester of pregnancy that results in autistic children is influenza, although most mothers of neurologically impaired children have no reported signs/ symptoms of a viral infection during pregnancy.(81) Also, maternal immune activation (MIA) in the infected mother but without apparent contagion in the developing fetus is the form most commonly associated with autism in the newborn. This would make MIA an environmental risk factor for the fetus, not necessarily due to a direct infection in the baby. (82) Thinning of the myelin layer in the CNS or an overall reduction of neuronal size correlates with the occurrence of autism.(83-85) In insulin growth factor 1 (IGF-1) null mice, myelin thickness and neurologic stem cell proliferation/ differentiation are reduced. $(86,87)$

Dietary factors are also under consideration as environmental contributors to ASD.(88) A several-fold 
reduction in the proportion of $\mathrm{v}-3$ fatty acids in lipid intake over the past few generations, and potential exacerbation of the impact of this deficiency by GI disturbances in ASD (89), may contribute to abnormal fatty acid profiles in ASD (90) that could affect neuronal processing (91), though rigorous evidence for the efficacy of essential fatty acid supplementation in ASD is still weak (92). Nutritional insufficiencies that may reduce the availability of substrates for neuronal metabolism and increase vulnerability to oxidative stress (93) may result from self-restriction of intake common in ASD (94), and this may be further complicated by ingestion of toxicants and heavy metals as food contaminants.(93)

Environmental exposure to the organic aromatic compound p-cresol (4-methylphenol) is relatively common and occurs through the skin, as well as the GI and respiratory systems. However, the largest and most widespread source of this compound is represented by some gut bacteria which express p-cresol synthesizing enzymes not found in human cells. Potential sources of p-cresol excess in ASD, such as gut infection, chronic constipation, antibiotics, abnormal intestinal permeability, and environmental exposure, are being investigated. p-cresol may contribute to worsen autism severity and gut dysfunction, often present in autistic children. It may also contribute to a multibiomarker diagnostic panel useful in small autistic children.(95)

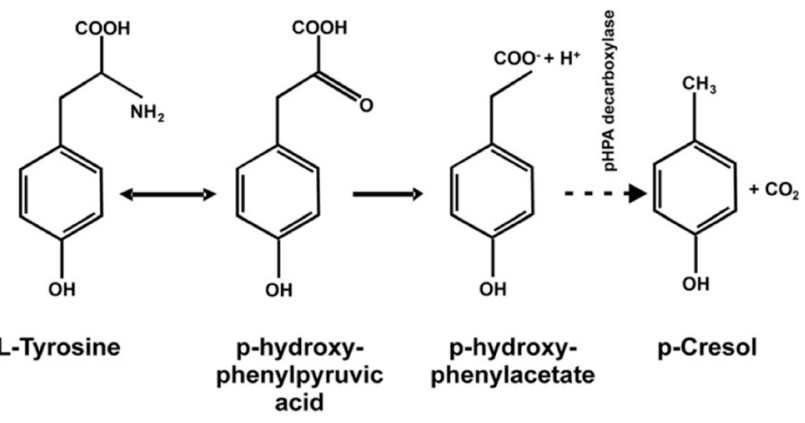

Figure 2. Synthesis of p-cresol from tyrosine by gut bacteria expressing pHPA decarboxylase (hyphenated arrow). Artificial sources of exposure: disinfectants and preservatives, stabilizers in washing and cleaning products , paints, fillers, solvents, adhesives for surface treatments, corrosion inhibitors, impregnation materials, perfumes and cosmetics, combustion from incinerators and cigarette smoke. (95) (Adapted with permission from Elsevier).

\section{Redox / Methylation Hypothesis of ASD}

The role of environmental factors in the etiology of ASDs is supported by extensive literatures.(88) Exposure to heavy metals and xenobiotics is a feature of contemporary life and it may also contribute to neurodegenerative disorders, including Parkinson and Alzheimer diseases (96,97), indicating that the human brain is an especially sensitive target. Most of these agents directly or indirectly influence cellular redox status and the associated pathways of sulfur metabolism by promoting cellular oxidative stress in vulnerable individuals and initiating adaptive responses that include reduced methylation activity. $(98,99)$ Methylation has an important role in the synthesis of myelin basic protein, an essential component that confers compactness to myelin. This is a critical step because the correct synthesis and assembling of myelin are fundamental in the development of the central nervous system. $(100,101)$ In addition, decreased DNA methylation increases expression of genes under the negative influence of methylation, disrupting epigenetic silencing of chromosomal regions linked to ASDs and leading to developmental delay, deficit in attention, and neuronal synchronization, which are typical hallmarks of autism. $(23,99)$ It may be hypothesized that autism results from a combination of genetic and biochemical susceptibilities in the form of a reduced ability to excrete $\mathrm{Hg}$ and/or increased environmental exposure at key times in development. This would mean that individuals exposed to relatively high $\mathrm{Hg}$ could be affected even if their bodies were innately efficient eliminators (54).

In order to clinically examine evidence for the above hypothesis, it is important to analyze biomarkers for $\mathrm{Hg}$ susceptibility and toxicity in patients diagnosed with an ASD. Namely, it was previously demonstrated that the trans-sulfuration pathway products of glutathione (102) and sulfate (103) were related to $\mathrm{Hg}$ excretion rates, and that the heme synthesis pathway products of urinary porphyrins can provide specific profiles that reflect $\mathrm{Hg}$ toxicity (104). Evidence from studies on blood biomarkers related to oxidative stress in ASD patients compared with healthy controls shows a consistent alteration of some biomarkers, i.e., an increase in the glutathione disulfide (GSSG) (45\%) and a decrease in glutathione (GSH) $(27 \%)$, glutathione peroxidase (GPX) (18\%), methionine (13\%), and cysteine (14\%) (105).

Genetic polymorphisms adversely affecting sulfur metabolism, methylation, detoxification, dopamine signaling and the formation of neuronal networks occur more frequently in autistic subjects. On the basis of these observations, a "redox/methylation hypothesis of autism" is described, in which oxidative stress, initiated by environment factors in genetically vulnerable individuals, leads to impaired methylation and neurological deficits secondary to reductions in the capacity for synchronizing neural networks.(99) 


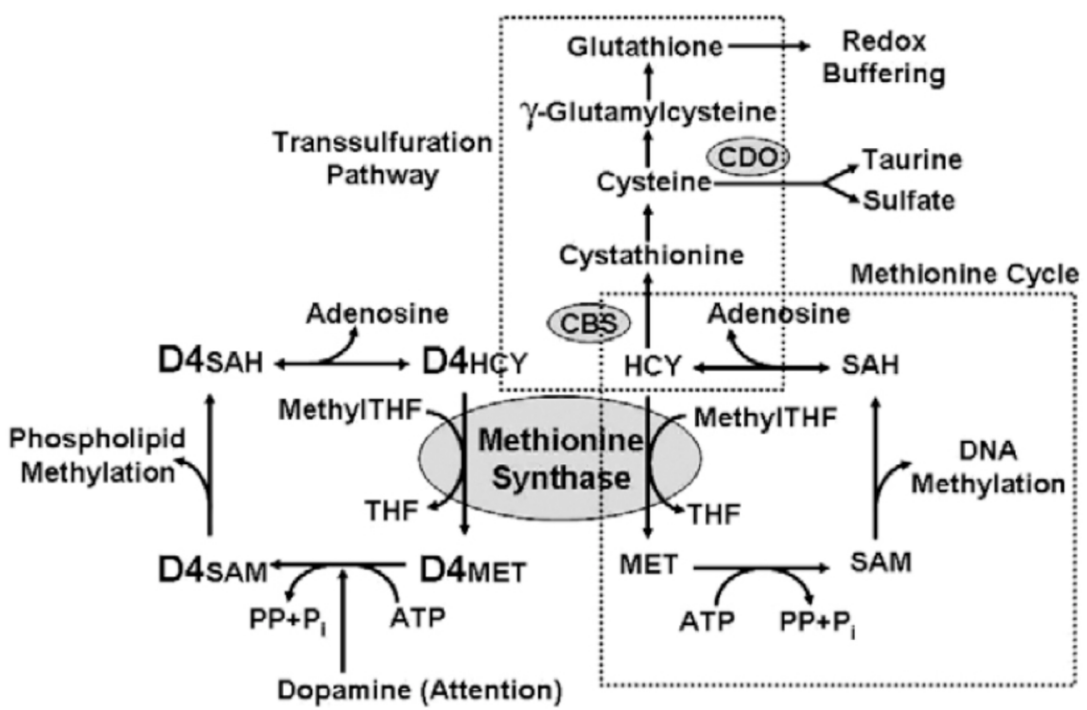

(B)

\section{OXIDATIVE STRESS}

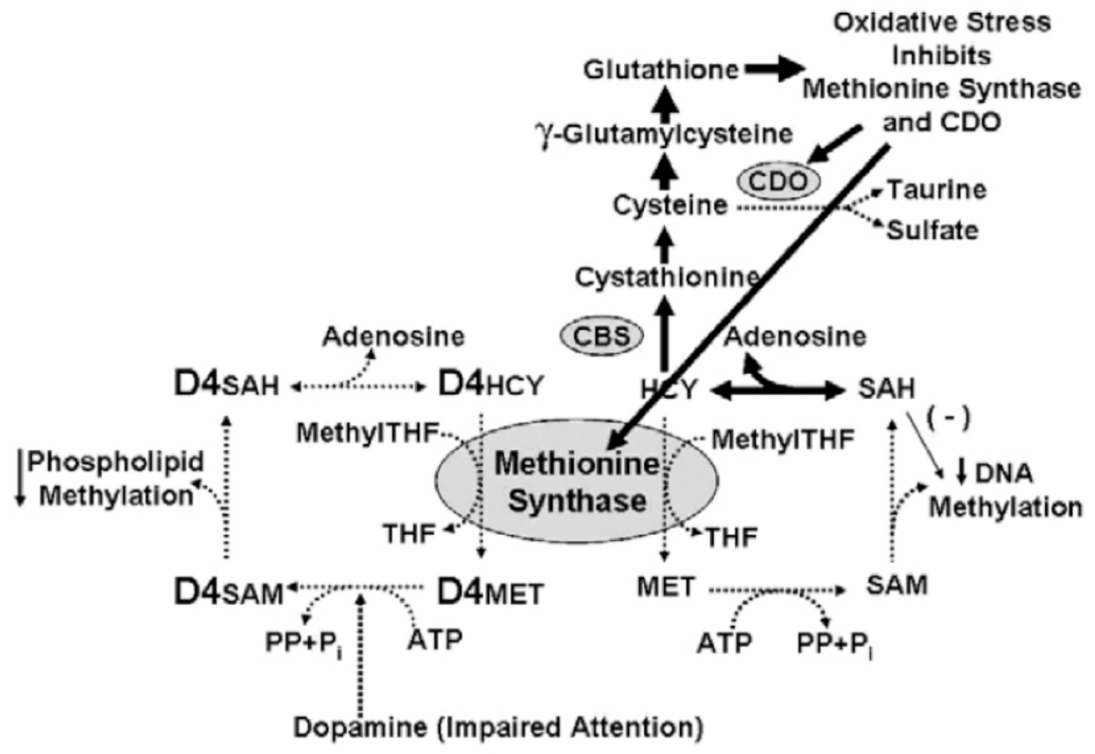

Figure 3. Adaptations of sulfur metabolism to oxidative stress. (99)(Adapted with permission from Elsevier).

While individual xenobiotics and heavy metals each produce a unique constellation of pathological insults reflecting their individual chemical reactivity, almost all such agents directly or indirectly impact cellular redox status and associated pathways of sulfur metabolism.(98) Indeed, sulfur metabolism can be considered a "final common pathway" of toxicity, reflecting the summed influence of diverse environmental insults. This role is no great surprise, since sulfur metabolism has evolved as a primary defense system against stressful insults, orchestrating a large number of processes to maintain normal cellular function and survival.(106)

Recent studies of sulfur metabolism in children with autism reveal a pattern of abnormalities indicative of the presence of oxidative stress and impaired methylation.(107) We previously described the shared ability of a number of neurodevelopmental toxins, including $\mathrm{Pb}, \mathrm{Hg}$, thimerosal and alcohol, to potently inhibit activity of methionine synthase (MS), the ubiquitous vitamin B12 and folatedependent enzyme that converts homocysteine (HCY) to methionine.(108) As described below, MS activity is highly sensitive to oxidative stress. MS activity is also required 
for dopamine-stimulated phospholipid methylation (PLM), a unique signaling activity of the D4 subtype dopamine receptor, that appears to be critical for synchronization of brain activity during attention.(109,110) Impaired synchronization is a feature of autism, and a large body of literature links D4 dopamine receptors to ADHD $(111,112)$, suggesting that impaired methylation activity of MS could limit dopamine-stimulated PLM in autism and ADHD.

Based upon the above, a redox/methylation hypothesis of autism is advanced, proposing that environmental insults initiate autism in genetically sensitive individuals by promoting cellular oxidative stress and initiating adaptive responses that include reduced methylation activity. Impaired methylation in turn leads to developmental delay and deficits in attention and neuronal synchronization that are hallmarks of autism.(99)

Thus increased exposure to environmental stressors places an entire population at risk, but genetically vulnerable subpopulations are most likely to manifest a particular disorder, such as autism. In this regard, increased oxidative stress can be viewed as a condition where certain genetic variations prove useful or harmful.(99) The ability of heavy metals to bind to thiol groups and to disrupt pathways of sulfur metabolism is well established. Indeed, the traditional name for thiols is mercaptans, recognizing their affinity for Hg. Sulfur metabolism is important for the excretion of xenobiotics (e.g. sulfation and formation of mercapturic acid derivatives) and their oxidized metabolites contribute to oxidative stress. Since many pesticides and preservatives function by disrupting redox events, it is not surprising they should exert similar effects in humans.

Currently, the diagnosis of ASD is based solely on the presence of a complex phenotype as assessed by a qualified professional. Several biomarkers-hyperserotoninemia (113), oxidative metabolism biomarker (114) and a tryptophan: large neutral amino acid ratio (115), have been shown to be associated with autistic traits. However, none of these have proven to be useful as a screening test, let alone for clinical diagnosis. The Phenotype MicroArray platform (Biolog, CA, USA) was used to profile multiple metabolic pathways in individuals with various neurodevelopmental disorders, it showed a significant decrease in the utilization of tryptophan as an energy source in cell lines from individuals with ASD, as measured by reduced generation of NADH.(116)

ASD studies suggests an impairment of tryptophan metabolism. Its metabolism involves two pathways which result in the production of $\mathrm{NADH}$, especially via the kynurenine pathway, way, which leads to the synthesis of $\mathrm{NAD}^{+}$, the precursor of NADH. The observed decreased level of NADH generation when tryptophan is the sole energy source therefore might reflect a dysregulation of various reactions along these pathways, particularly the kynurenine pathway, as it is the major route of tryptophan metabolism (117). Although only a small fraction of tryptophan is metabolized along the serotonin-melatonin pathway, it is important for the generation of serotonin in the brain. Serotonin is an important neurotransmitter because of its involvement in multiple brain functions (118). Recent work found placental cells are capable of synthesizing serotonin by utilizing tryptophan provided via the maternal blood supply.(119) This source of serotonin is probably important for the development of the forebrain, whose disrupted organization has been one of the most consistent anatomical findings in ASD patients.(22) Last, the measurement of serotonin levels has been the most consistent biomarker for ASD.(119) Tryptophan metabolism can affect brain development and function via a multitude of avenues, either by affecting neurotransmitters, neuronal receptor function or neuronal mitochondrial function.(120)

ASD could arise from multiple subpathological alterations, which, in total, lead to a behavioral phenotype. Thus, it is quite possible that impairment of the metabolism of tryptophan, by any one of numerous means, provides the unifying model that explains the heterogeneity of ASD and the past difficulty in identifying a universal biomarker. Perhaps measurement of the decrease in tryptophan metabolism in cells from patients will provide a reliable screening test for ASDs (120).

\section{Immune Dysfunction in ASD}

Substantial evidence suggests that the immune system plays an important role in the pathogenesis of autism.(121-123) While the exact mechanism of immune dysfunction in autistic patients remains undefined, two general possibilities have been outlined. First, there might be a defect in immune regulation that causes hyper- or hypo-activation of the cellular components of the nervous system. This causes a homeostatic imbalance among the immunoregulatory factors in the brain and/or other aVected organs such as the GI tract. Second, an alternative mechanism of autistic development has been viewed as autoimmune reaction directed toward a specific target molecule in the brain.(124)

Maternal infection is a risk factor for many neurodevelopmental disorders, including autism.(125127) It was reported that $43 \%$ of mothers with an autistic child experienced upper respiratory tract, influenza-like, 


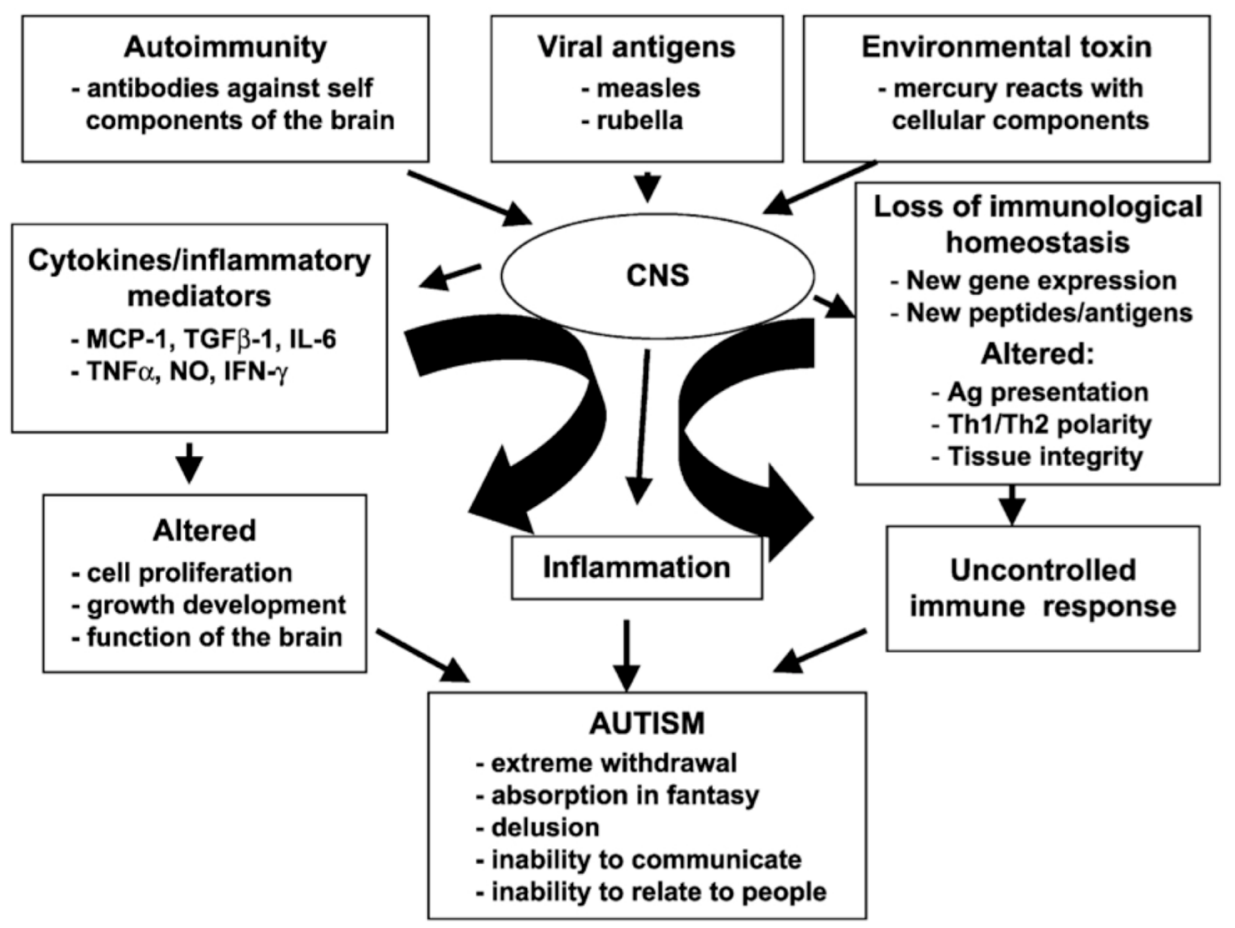

Figure 4. Schematic presentation of immunopathogenesis of autism. (124) (Adapted with permission from Elsevier).

urinary, or vaginal infections during pregnancy compared to only $26 \%$ of control mothers.(128) Studies show that, in rats, maternal exposure to infection alters proinflammatory cytokine levels in the fetal environment, including the brain. It has been proposed that these changes may have a significant impact on the developing brain. $(129,130)$ These observations suggest certain cases of autism may be a sequela of pathogenic infections, especially those of a viral origin. $(125,127,131)$ Individuals with autism show increased pro-inflammatory cytokines in the brain, as well as activation of resident immune cells known as microglia. Additionally, antibodies that target brain tissues have been described in both children with autism and their mothers. These immunological phenomena may interfere with normal brain development and function; potentially contributing to the development and/or symptoms of ASD (132). This inflammation-based mechanism details how pro-inflammatory cytokines such as tumor necrosis factor (TNF)- $\alpha$, interleukin (IL)-1 $\beta$, and IL-6 arising from maternal inflammation, infection, allergy, and, possibly, autoimmunity, pass through the placenta, enter the fetal circulation, cross the blood-brain barrier (BBB), cause aberrant neuronal growth and plasticity within the fetal CNS, and facilitate development of chronic inflammatory environments within the fetus that predispose it to lifelong co-morbid psychiatric and systemic pathologies. Such a mechanism could account for many of the observed symptoms observed in autistic individuals such as hypersensitivity to environmental stimuli, object fixation, echolalia, repetitive behaviors, chronic enterocolitis and, at the extreme, savantism (133).

First, a hyper-inflammatory state in the mother causes pro-inflammatory cytokines to cross the placenta into the fetus. Next, the maternal pro-inflammatory cytokines enter the fetal circulation and cross $\mathrm{BBB}$ at the choroids plexus and meninges to activate microglia and stimulate the growth of more microglia within the brain to produce an excess of pro-inflammatory cytokines, a "cytokine-storm". The "cytokine-storm" stimulates excessive neuron growth through the up-regulation of nerve growth factor (NGF). Finally, the pro-inflammatory cytokines influence neuron plasticity within the hippocampus and cerebellum to create the symptoms of autism. Chronic hypothalamic-pituitaryadrenal (HPA)-axis and sympathetic nervous system (SNS) activation create life-long peripheral systemic pathologies (i.e., enterocolitis) sometimes seen in autistic individuals.

Depression in humans is often associated with elevated levels of pro-inflammatory cytokines (134). It has been demonstrated that pro-inflammatory cytokines increase the activity of HPA axis. Persistently high levels of proinflammatory cytokines within the CNS could lead to the chronic activation of the HPA-axis and cause the depression and anxiety often seen as co-morbid with autism. Data from the John's Hopkin's University Interactive Autism Network 
(JHU IAN) longitudinal study indicate that an abnormally high percentage of mothers in their study experienced a diagnosed depression ( $45 \%$ vs. the normal depression rate of approximately $18 \%$ ) and anxiety when compared with other disorders. A clinically diagnosed depression (and possibly anxiety) in mothers is a potential diagnostic marker of an elevated systemic pro-inflammatory state, a cytokineinduced depression, that can be passed to the developing fetus.(133) If such a mechanistic pathway can lead to autism, then perhaps diagnosed maternal depression could serve as an early warning sign for autism. In such cases, a preventative strategy of administering anti-inflammatory cytokines or drugs to the mother, or potentially directly to the fetus, might minimize or even eliminate the chance of having an autistic child.(133)

Systemic immunologic aberrations in ASD have been linked with both autoimmunity, describing antibodies reactive for central nervous system (CNS) proteins with the potential for neuronal tissue destruction, and with dysfunctional immunity such as abnormalities or deficits of function in immune cell subsets. The plausibility of hypotheses concerning immune system alterations in ASD is derived from the recognized roles of the immune system in early neurodevelopment and the ability of these alterations to influence patterns of behavior.(135)

In ASD, a number of neuroactive compounds that also share immunomodulatory properties have been implicated in the disease process, for example, elevated platelet serotonin levels are observed in approximately one-third of children with autism.(136-138) Similarly, it has been hypothesized that autism may be a result of abnormal levels or activity of opioid peptides, which can act as cytokines conferring their actions through receptors on peripheral blood and/or glial cells. In addition, neuropeptides, such as oxytocin and vasopressin, have been implicated in social recognition, affiliation and attachment behaviors. Moreover, neuropeptides may act synergistically with cytokines to alter immune or neuronal function. For example vasoactive intestinal polypeptiide (VIP) synergizes with TNF- $\alpha$ to induce dendritic cell maturation.(139) Various immune function abnormalities have been widely reported in autistic individuals. $(140,141)$

Studies of autistic individuals have found an increased frequency of autoantibody production. ASD patients has shown that approximately $30-70 \%$ of autistic patients have circulating anti-brain autoantibodies (141-148) including autoantibodies to a serotonin receptor (149), myelin basic protein (150) and, most recently, as yet unknown antigens from adult brain tissue extract.(151) The findings of autoimmunity in families and the plethora of anti-brain antibodies suggest that in some patients, autoantibodies that target the CNS may be a pathological or exacerbating factor in neuronal development in children with ASD.(135) Various studies established an association between ASD and a family history of autoimmune diseases. $(128,152,153)$ This was first documented in case reports (154) and later confirmed in comprehensive epidemiological studies for approximately $40 \%$ of children with autism. $(155,156)$ In particular an association with autoimmune thyroiditis or hypothyroidism (157), rheumatic fever (158), rheumatoid arthritis, celiac disease, ulcerative colitis, psoriasis, family history of type 1 diabetes has been found $(156,159)$. One possible hypothesis that would connect the autoimmune components elaborated upon above with the clinical findings in autism would be an early-life immune insult leading to changes in the vulnerable embryonic and infantile brain. (160)

In conclusion, various types of immunological evidence (brain antibodies, serum cytokines, family history, and immunogenetics) point to a relationship between ASD and the immune system.

\section{The Gut - Brain Axis}

GI disturbances are commonly reported in children with autism, complicate clinical management, and may contribute to behavioral impairment.(161) Reported functional disturbances include increased intestinal permeability (162), deficient enzymatic activity of disaccharidases (163), increased secretin-induced pancreatico-biliary secretion (163), and abnormal fecal Clostridia taxa.(164-166) Some children placed on exclusion diets or treated with the antibiotic vancomycin are reported to improve in cognitive and social function $(167,168)$. Furthermore, a recent study found a strong correlation between GI symptoms and autism severity.(169) The bidirectional signaling between the GI tract and the brain is vital for maintaining homeostasis and is regulated at the neural (both central and enteric nervous systems), hormonal and immunological levels. Perturbation of these systems results in alterations in the stress-response and overall behavior.(170)

Current studies on ASD indicate that genetic and environmental factors both contribute to its etiology (171). In particular, the existence of various GI related comorbidities in ASD, such as functional GI disorders (163), food intolerances/allergies (172) and impaired detoxification processes (107), have been identified as contributing to 
its etiology and in some instances have been linked with altered gut microbiota. Recent studies have identified that the actions of the microbiota and their metabolites can significantly alter host health, including modulation of brain activity and behavior.(170)

The enteric nervous system, which contains as many as 1 billion neurons, is located within the wall of the GI tract.(173-175) Neurological diseases and syndromes are widely associated with a variety of GI symptoms (174), and abnormal behaviors are frequently reported in patients with GI disorders (176). Research using modern brain imaging techniques has shown a considerable overlap between regions involved in the processing of visceral sensation and regions important for emotional regulation (177), suggesting that emotional state has an important influence on the function of the GI tract and vice versa.(173) The human large intestine harbors hundreds of different bacterial species and recent international efforts using DNA sequencing methods have demonstrated a high degree of variation in these populations.(178-180) Alterations in the GI microbiota can drive intestinal inflammation (181), increase gut permeability (182), cause food allergies (172) and change GI $\mathrm{pH}$ values, which influence digestive enzyme production and action (183). Of particular interest is the growing evidence for a role of intestinal microbiota in influencing activities distant to the gut, including activities of the brain.(184)

Dietary carbohydrates and proteins that have resisted digestion in the small intestine are the main substrates for fermentation in the large intestine.(185) Alterations in GI bacterial fermentation product profiles could reflect changes in GI microbiota composition and/or activities, as well as be indicative of GI disturbance. Bull et al. were first to suggest microbial metabolites could be used as biomarkers in autism identifying that urinary indolyl-3-acryloylglycine (IAG) was higher in individuals with autism compared with controls.(186) Of particular interest is propionate which is a weak acid that exists in ionized and non-ionized forms at physiological $\mathrm{pH}$, allowing it to cross the gut-blood barrier and blood-brain barrier to enter CNS (187) and induce widespread effects on CNS function, including neurotransmitter synthesis and release, calcium influx, intracellular $\mathrm{pH}$ maintenance, mitochondrial function, immune activation and gene expression (188).

A review paper examining propionate's biological effects concluded that propionate is an important link in the nutrition, microbiota and physiology triangle.(189) Elevated levels of propionate in the CNS, can result in neuroinflammation and induce oxidative stress. $(190,191)$ A recent study investigated the persisting neurotoxic effects of propionate via oral administration of propionate to rats and found many resulting metabolite changes are consistent with changes observed in individuals with ASD and suggested propionate could play a role in the etiology of autistic biochemical features, particularly oxidative stress. (187)

Increased fecal concentrations of other major shortchain fatty acids (SCFA), namely, acetic and butyric acids as well as total SCFA in children with ASD. Similar differences in total SCFA and acetic acid concentrations have been reported by Tjellstrom et al. (192) in children with celiac disease compared with controls. Recent studies suggest that SCFA, in particular acetic acid, could have a role in gut epithelial barrier function. $(193,194)$ Increased intestinal permeability has been reported in ASD $(162,195)$ and this could be related to changes in fecal production of acetic acid or other SCFA.(196) Many protein fermentation products, such as phenols and ammonia can be detrimental to the GI tract. These compounds are absorbed from the colon into the systemic circulation, detoxified by the liver and then excreted in the urine or remain unabsorbed and excreted in the faeces.(197) Increased pcresol concentrations in the intestinal lumen, perhaps in conjunction with excessive carbohydrate availability, may influence the microbiota profile.(161) Elevated urinary levels of pcresol have been found in children with ASD compared with controls in one study (198) whereas lower urinary levels of pcresol sulphate in children with ASD were reported in another.

The use of gut microbiota and fermentation products as biomarkers may enable the early identification of ASD children at risk of GI disturbance and thereby earlier initiation of interventions.(184) Taken together, these findings support a gut-microbiome-brain connection in a mouse model of ASD and identify a potential probiotic therapy for GI and particular behavioral symptoms in human neurodevelopmental disorders.

\section{Biomarkers for Diagnosis and Screening of ASD}

ASD is difficult to diagnose in the neonate where distinct anatomical defects are not apparent other than head size and intraocular distance. Hence, clinical diagnoses are delayed to later in childhood (2-4 years), a time when nerve networking and patterning are already being established. At present, diagnosis of this mental disorder is largely by case history, family/clinical observations, checklists, interviews, 
questionnaires and phenotypic traits such as head size, lack of eye contact and repetitive, obsessive-compulsive behaviors.

The fetal/infant brain is highly susceptible to oxidative, immunologic and environmental stresses during postnatal development that could affect gene expression during the establishment of neurite outgrowths, circuitry and synaptic connections. Thus, ASD encompasses a heterogeneous, complex cluster disorder with multiple genes acting in various combinations and per-mutations.(200) By the time a firm diagnosis is made through conventional psychological testing (typically around age 2 or older), the neurologic damage, especially dysmyelination, is advanced. If the etiology of autism were known, the possibility of designing a treatment to mend the defective neuroproliferative process early might be feasible.(82)

In the prior reports, it was proposed that the key to comprehending the pathogenesis of autism is IGF deficiency.(201) Among several bioactive functions, this agent stimulates oligodendrocytes in the fetus and newborn to myelinate developing CNS neurons.(86) IGF is a major factor in promoting the myelination process. Biological or environmental conditions which reduce the availability of free IGF could diminish the production of serviceable myelin, thereby inducing malfunction in the nervous system. Depressed fetal IGF is a consequence of attenuated intrauterine placental processes.(82) The primary issues which reduce levels of IGF are gene polymorphisms/ mutations (202), inadequate nutrition (203), advanced parental age (204), and immune activation (205). Genetic alterations account for only a small percentage of the cases of autism (206). Immunologic reaction in response to MIA in the pregnant patient results in large increases of IL-6, among a number of cytokines.(207) In such cases, IL-6 is found elevated in the placenta and the amniotic fluid in particular. (208) The presence of increased IL-6 alters fetal neural cell adhesion, migration, and synaptic formation.(209) Through attenuation of intra- and inter-cellular signaling factors, the increase of IL6 results in a reduced synthesis and supply of IGF to the developing fetus.(205) Infections occurring early in pregnancy elicit greater pathologic effects on the development of the fetal CNS than those arising later.(209)

To account for a postpartum persistence of myelin inadequacy in autism, a rational explanation concerns myelin basic protein (MBP), one of the major structural proteins of CNS myelin. IL6, which can traverse the bloodbrain barrier, is often found in the brains of autistic children long after delivery and may represent a subacute, continuing process in the CNS $(210,211)$. Dysmyelination may also result from maternal antibody products from degenerative viral attacks on neurons being passed antepartum to the fetus or autoimmunity persisting in the neonates after birth. Both children and their mothers often exhibit elevated levels of anti-MBP. This may explain the lasting postpartum effect of MIA on the child. These antibodies are found in at least $58 \%$ of autistic children in contrast to $9 \%$ in normal controls.(38)

Myelination of the fetal CNS begins in the late second trimester, and continues for several months after birth. (212) Insufficient IGF could disrupt normal neurogenesis and maintenance, thereby augmenting the production of anti-MBP and apoptosis.(213) In situations where reduced IGF may compromise neuronal survival, neurogenesis, and brain plasticity, parallel changes in brain-derived neurotrophic factor (BDNF) and serotonin are observed. (213) To maintain proper neural homeostasis, a decrease in one factor (e.g., IGF) is counterbalanced by a rise in another (e.g., serotonin).(214) Serotonin influences neurogenesis, neuronal differentiation, and synaptogenesis.(215) Elevated serotonin levels are found in at least $30 \%$ of autistic children, as well as in many of their parents and siblings. On the other hand, no significant difference with BDNF levels is found between groups of autistic and normal people. $(216,217)$ This elevation appears related to polymorphisms of the serotonin transporter gene.(218) Deviations in serotonin stabilization can lead to persistent dysfunctional changes in overall behavior patterns. $(219,220)$

In order to judge whether or not a newborn might develop autism, it is proposed that circulating IGF, serotonin, and anti-MBP be measured at birth. If one or more of the three parameters are abnormal and the occurrence of each with autism is known, an autism index (AI) can be calculated. In this way, a more definitive estimation of the prognosis can be derived, rather than depending on just a single variable.(82)

Calculation of AI (82):

$$
A I=[p 1 n 1+p 2 n 2+p 3 n 3] / 0.1
$$

AI: autism index; likelihood of later development of autism p: weighted probability of depressed/elevated biomarker in autism

n: absolute percent (decimal) depression/elevation of biomarker below/above norm in the test case.

1: IGF; 2: anti-MBP; 3: serotonin 


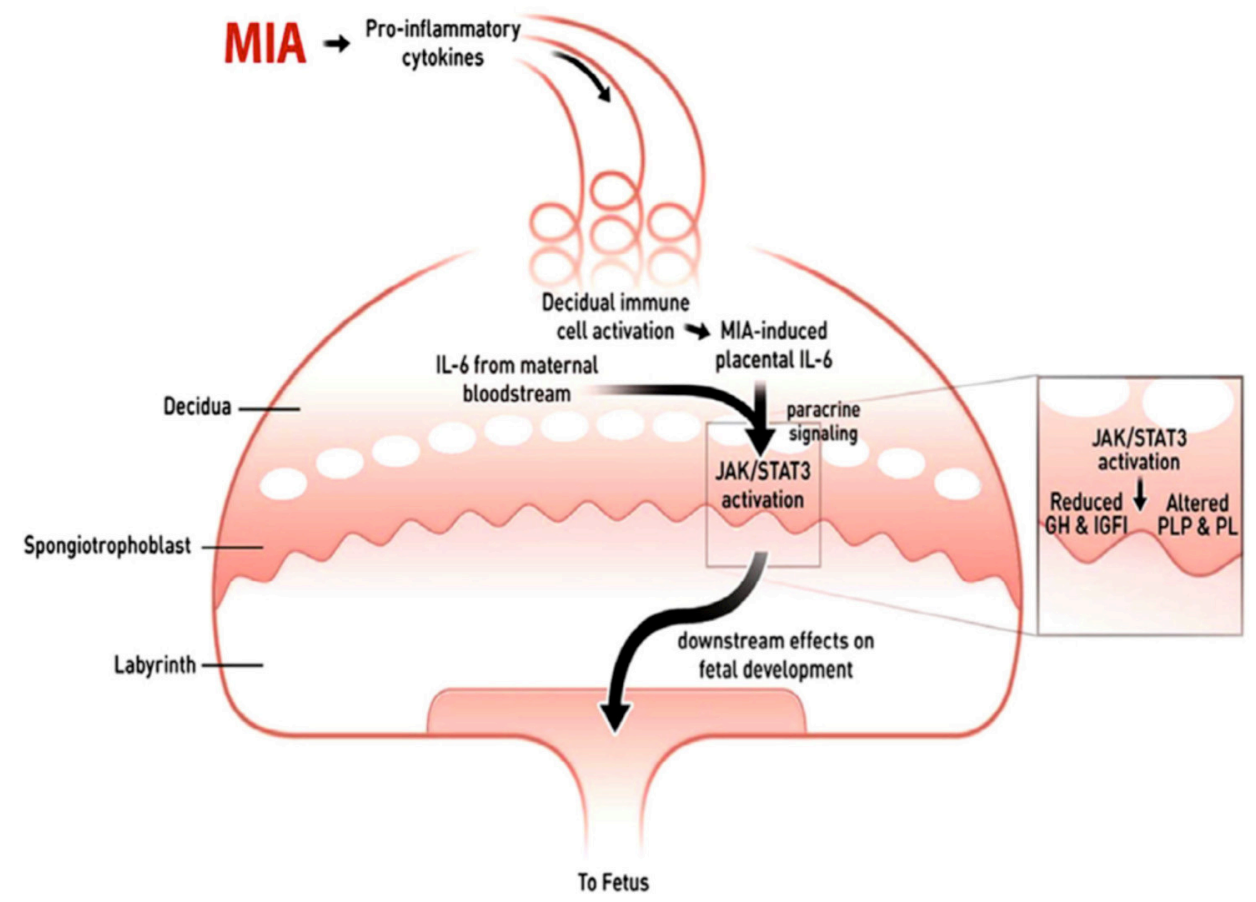

Figure 5. Maternal immunologic activation, secondary to an inflammatory process, promotes the release of IL6. The cytokine depresses IGF-1 production and release to the fetus (82) (Adapted with permission from Elsevier).

1) Hypothetical example of an (impending) autistic newborn:

\begin{tabular}{ccc}
\hline IGF & Anti - MBP & Serotonin \\
\hline $\mathrm{p}_{1}=0.91$ & $\mathrm{p}_{2}=0.58$ & $\mathrm{p}_{3}=0.20$ \\
$\mathrm{n}_{1}=0.20$ & $\mathrm{n}_{2}=0.23$ & $\mathrm{n}_{3}=0.15$ \\
\hline$(0.91)(0.20)+(0.58)(0.23)+(0.20)(0.15)] / 0.1$ & $=3.46$
\end{tabular}

2) Hypothetical example of an unaffected newborn: AI 0.00

The three "insults" discussed here, which can alter normal neurogenesis, myelination, and neurologic function, describe factors that are often associated with autism. They can be modified directly or indirectly by overt or covert maternal inflammatory processes during pregnancy. This may lead to activation of the immune system and release of cytokines. These factors could be viewed as biomarkers evident before the psychoneurologic manifestations of autism become apparent in neonates.(82) Thus, it would be preferable to measure autism potential at or before birth. The autism index proposed here is intended to provide this early assessment.

As ASD involves a neurobehavioral phenotype, it can likely arise from many different defects. The phenotype will be common, but the genotype different, most likely a complex one. Assessment of the utilization of tryptophan may provide a window into the etiology behind the heterogenetic nature of ASDs. It may reflect the level of dysregulation inherent in the metabolic pathways of tryptophan and even the proper function of the membrane transporters for this essential amino acid. There exist many points along the metabolic pathways of tryptophan in which pathogenic events could arise that have been associated with the phenotype of ASD.(120)

Many children with ASD also have "allergic-like" symptoms, but test negative implying mast cell activation by non-allergic triggers. Angelidou et al. measured by Milliplex arrays serum levels of 3 neuropeptides that could stimulate mast cells in children with autistic disorder only neurotensin (NT) was significantly increased from $60.5 \pm 6.0$ $\mathrm{pg} / \mathrm{ml}$ in controls to $105.6 \pm 12.4 \mathrm{pg} / \mathrm{ml}$ in autistic disorder $(\mathrm{p}=0.004)$. NT could stimulate immune cells, especially mast cells, and/or have direct effects on brain inflammation and ASD.(221)

Decreased trans-sulfuration metabolites/increased urinary porphyrin metabolites associated with $\mathrm{Hg}$ susceptibility/toxicity in a cohort of participants diagnosed with an ASD. Furthermore, a significant correlation was found between the clinical severity of participants diagnosed with an ASD, as measured/indicated by the CARS, and urinary porphyrins associated with $\mathrm{Hg}$ toxicity. Finally, a significant relationship was observed between increasing 
levels of plasma oxidized glutathione and increasing urinary porphyrins associated with $\mathrm{Hg}$ toxicity.(54)

A biomarker can be defined as a biological variable significantly associated with the disease of interest and measurable directly on a given patient or more often on his/her biological specimens/bodily fluids, using sensitive and reliable quantitative procedures. Given the phenotypic heterogeneity of ASD and the well-recognized existence of many "autisms", each characterized by specific etiopathogenetic underpinnings (222), investigators are now striving to define a panel of autism biomarkers able to: (a) foster earlier and more reliable diagnoses, (b) predict developmental trajectories and treatment response, (c) identify individuals at high-risk, eventually leading to the establishment of preventive health care strategies, (d) contribute to dissect ASD into more discrete clinical entities, and (e) possibly even reveal unknown causes or mechanisms of disease. Many autism biomarkers have been proposed to date $(9,186,223,224)$, but scientific, ethical, clinical and practical issues still pose a major challenge to their use in clinical practice (225). The sensitivity and specificity of each single biomarker in complex disorders like autism is generally low. The biological complexity of ASD will likely require age- and sex-specific panels, each including several biomarkers belonging to different domains (biochemical, brain imaging, dysmorphological, electrophysiological, genetic, immunological, etc).(95)

Biomarkers discussed within this article should be particularly useful in understanding the connection between genetic predisposition and environmental triggers since biomarkers can reflect genetic polymorphisms that disrupt metabolic pathways as well as environmental exposures. Most importantly, biomarkers are potentially useful for identifying those individuals who are most vulnerable to environmental triggers so they can be protected from developing pathology associated with autism.(226) The pace of autism research and gained knowledge has increased exponentially in the last decade. This is true not only in the clinic, but also at the research bench. In the next 5-10 years, we can expect the autism field to expand and broaden its present base of knowledge in the areas of toxic metals, nutrition, GI biochemistry, genetic loci, medical imaging, autoimmunity and inflammation of the brain.(227)

\section{Conclusion}

ASD is currently diagnosed using only behavioral criteria. This article reviews evidence that ASD is a multifaceted biomedical disorder characterized by oxidative stress, decreased methylation capacity, limited trans-sulfuration production of cysteine and GSH, mitochondrial dysfunction, intestinal dysbiosis, increased toxic metal burden, cerebral hypoperfusion, and complex immune dysregulation. The biomarkers discussed in this article are useful to guide the selection, efficacy, and sufficiency of biomedical interventions, which would likely include nutritional supplementation, dietary changes, and specific medications for treating GI pathogens and reducing inflammation.

\section{References}

1. Kidd PM. Autism, an extreme challenge to integrative medicine. Part: 1: The knowledge base. Altern Med Rev. 2002; 7: 292-316.

2. Autism: an environmental illness. In: Jepson B. Changing the Course of Autism. Boulder, CO: Sentient Publications; 2007. p.42-6.

3. Posey DJ, Stigler KA, Erickson CA, McDougle CJ. Antipsychotics in the treatment of autism. J Clin Invest. 2008; 118: 6-14.

4. Bryson SE, Smith IM. Epidemiology of autism: Prevalence, associated characteristics, and implications for research and service delivery. Ment Retard Dev Disabil Res Rev. 1998; 4: 97-103.

5. Klin A, McPartland J, Volkmar FR. Asperger Syndrom. In: Paul R, editor. Handbook of Autism and Pervasive Developmental Disorders. New York: John Wiley \& Sons, Inc.; 1987. p.86-126.

6. Schonauer K, Klar M, Kehrer HE, Arolt V. [The course of infantile autism through adulthood. An overview of long-term follow-up data]. Fortschr Neurol Psychiatr. 2001; 69: 221-35.

7. Volkmar FR, Klin A. Issues in the classification of autism and related conditions. In: Volkmar FR, Paul R, Klin A, Cohen D, editors. Handbook of Autism and Pervasive Developmental Disorders. 3rd Ed, Vol 1. Hoboken, NJ: John Wiley \& Sons, Inc.; 2005. p.5-41.

8. Barbaresi WJ, Katusic SK, Voigt RG. Autism: a review of the state of the science for pediatric primary health care clinicians. Arch Pediatr Adolesc Med. 2006; 160: 1167-75.

9. Ecker C, Marquand A, Mourão-Miranda J, Johnston P, Daly $\mathrm{EM}$, Brammer MJ, et al. Describing the brain in autism in five dimensions-magnetic resonance imaging-assisted diagnosis of autism spectrum disorder using a multiparameter classification approach. J Neurosci. 2010; 30: 10612-23.

10. Weintraub K. The prevalence puzzle: Autism Count. Nature 2011; 479: $22-4$.

11. Ecker C. Autism biomarker for more efficacious diagnosis. Biomark Med 2011; 5: 193-5.

12. Ratajczak HV. Theoretical aspects of autism: causes - a review. J Immunotoxicol 2011; 8: 68-79.

13. Mottron L. Changing perceptions: The power of autism. Nature. 2011; 479: 33-5.

14. Geschwind DH. Levitt P. Autism spectrum disorders: developmental disconnection syndromes. Curr Opin Neurobiol. 2007; 17: 103-111.

15. Amaral DG, Schumann CM, Nordahl CW . Neuroanatomy of auism. Trends Neurosci. 2008; 31: 137-45.

16. Kanner L. Autistic disturbances of affective contact. Acta Paedopsychiatr. 1968; 35: 100-36.

17. DiCicco-Bloom E, Lord C, Zwaigenbaum L, Courchesne E, Dager SR, Schmitz C, et al. The developmental neurobiology of autism 
spectrum disorder. J Neurosci. 2006; 26: 6897-906.

18. Fombonne E. Past and future perspectives on autism epidemiology. In: Moldin SO, Rubenstein JLR, editors. Understanding Autism from Basic Neuroscience to Treatment. London: CRC Press; 2006. p.25-48.

19. Tuchman R, Rapin I. Epilepsy in autism. Lancet Neurol. 2002; 1: 352-8.

20. Lecavalier L. Behavioral and emotional problems in young people with pervasive developmental disorders: relative prevalence, effects of subject characteristics, and empirical classification. J Autism Dev Disord. 2006; 36: 1101-14.

21. Werner E, Dawson G. Validation of the phenomenon of autistic regression using home videotapes. Arch Gen Psychiatry 2005; 62: 889-95.

22. Casanova MF. The neuropathology of autism. Brain Pathol. 2007; 17: 422-33.

23. Persico AM, Bourgeron T. Searching for ways out of the autism maze: genetic, epigenetic and environmental clues. Trends Neurosci. 2006; 29: 349-58.

24. Watts TJ. The pathogenesis of autism. Clin Med Pathol. 2008; 1: 99103.

25. Pardo CA, Eberhart CG. The neurobiology of autism. Brain Pathol. 2007; 17: 434-47.

26. Herbert MR, Russo JP, Yang S, Roohi J, Blaxill M, Kahler SG, et al. Autism and environmental genomics. Neurotoxicology. 2006; 27: 671-84.

27. Minshew NJ, Williams DL. The new neurobiology of autism: cortex, connectivity, and neuronal organization. Arch Neurol. 2007; 64: 945-50.

28. Courchesne E. Brain development in autism: early overgrowth followed by premature arrest of growth. Ment Retard Dev Disabil Res Rev. 2004; 10: 106-11.

29. Courchesne E, Redcay E, Kennedy DP. The autistic brain: birth through adulthood. Curr Opin Neurol. 2004; 17: 489-96.

30. Courchesne E, Pierce K. Brain overgrowth in autism during a critical time in development: implications for frontal pyramidal neuron and interneuron development and connectivity. Int J Dev Neurosci. 2005; $23: 153-70$

31. Schumann CM, Hamstra J, Goodlin-Jones BL, Lotspeich LJ, Kwon $\mathrm{H}$, Buonocore $\mathrm{MH}$, et al. The amygdala is enlarged in children but not adolescents with autism; the hippocampus is enlarged at all ages. J Neurosci. 2004; 24: 6392-401.

32. Polleux F, Lauder JM. Toward a developmental neurobiology of autism. Ment Retard Dev Disabil Res Rev. 2004; 10: 303-17.

33. Bauman ML, Kemper TL. Structural brain anatomy in autism: what is the evidence. In: Bauman ML, Kemper TL, editors. The Neurobiology of Autism. Baltimore: Johns Hopkins University Press; 1994. p.119-45.

34. Bauman ML, Kemper TL. Neuroanatomic observations of the brain in autism: a review and future directions. Int J Dev Neurosci. 2005; 23: 183-7.

35. Courchesne E, Karns CM, Davis HR, Ziccardi R, Carper RA, Tigue $\mathrm{ZD}$, et al. Unusual brain growth patterns in early life in patients with autistic disorder: an MRI study. Neurology. 2001; 57: 245-54.

36. Haas RH. Autism and mitochondrial disease. Dev Disabil Res Rev. 2010; 16: 144-53.

37. Child Health Safery [homepage on the Internet]. Vaccination Causes Autism - Say US Government \& Merck's Director of Vaccines, 2010 [updated 2010 Jun 30; cited 2014 Nov 2] Available from: https:// childhealthsafety.wordpress.com/2010/06/30/vaccination-causesautism- $\%$ E2\%80\%93-say-us-government-merck $\% \mathrm{E} 2 \% 80 \% 99$ sdirector-of $\% \mathrm{C} 2 \% \mathrm{~A} 0$ vaccines/.
38. The autism web - making sense of the disease. In: Jepson B. Changing the Course of Autism. Boulder, CO: Sentient Publications; 2007. p.176-80.

39. Steinman G, Mankuta D. Umbilical cord biomarkers in autism determination. Biomark Med. 2014; 8: 317-9.

40. Rossignol DA, Frye RE. A review of research trends in physiological abnormalities in autism spectrum disorders: immune dysregulation, inflammation, oxidative stress, mitochondrial dysfunction and environmental toxicant exposures. Mol Physichiatry. 2012; 17: 389401.

41. Li Z, Dong T, Proschel C, Noble M. Chemically diverse toxicants converge on Fyn and c-Cbl to disrupt precursor cell function. PLoS Biol. 2007; 5: e35.

42. Grandjean P, Landrigan PJ. Developmental neurotoxicity of industrial chemicals. Lancet. 2006; 368: 2167-78.

43. Braun JM, Kahn RS, Froehlich T, Auinger P, Lanphear BP. Exposures to environmental toxicants and attention deficit hyperactivity disorder in US children. Environ Health Perspect. 2006; 114: 1904 9

44. Nigg JT, Knottnerus GM, Martel MM, Nikolas M, Cavanagh K, Karmaus W, et al. Low blood lead levels associated with clinically diagnosed attention-deficit/hyperactivity disorder and mediated by weak cognitive control. Biol Psychiatry. 2008; 63: 325-31.

45. Bouchard MF, Bellinger DC, Wright RO, Weisskopf MG. Attention-deficit/hyperactivity disorder and urinary metabolites of organophosphate pesticides. Pediatrics. 2010; 125: e1270-7. doi: 10.1542/peds.2009-3058.

46. Amr MM, Halim ZS, Moussa SS. Psychiatric disorders among Egyptian pesticide applicators and formulators. Environ Res. 1997; 73: 193-99.

47. Opler MG, Brown AS, Graziano J, Desai M, Zheng W, Schaefer $\mathrm{C}$, et al. Prenatal lead exposure, delta-aminolevulinic acid, and schizophrenia. Environ Health Perspect. 2004; 112: 548-52.

48. Palmer RF, Blanchard S, Wood R. Proximity to point sources of environmental mercury release as a predictor of autism prevalence. Health Place. 2009; 15: 18-24.

49. Windham GC, Zhang L, Gunier R, Croen LA, Grether JK. Autism spectrum disorders in relation to distribution of hazardous air pollutants in the San Francisco bay area. Environ Health Perspect. 2006; 114: 1438-44.

50. Roberts EM, English PB, Grether JK, Windham GC, Somberg L, Wolff C. Maternal residence near agricultural pesticide applications and autism spectrum disorders among children in the California Central Valley. Environ Health Perspect. 2007; 115: 1482-9.

51. Mutter J, Naumann J, Guethlin C. Comments on the article "the toxicology of mercury and its chemical compounds" by Clarkson and Magos (2006). Crit Rev Toxicol. 2007; 37: 537-49.

52. Kern JK, Jones AM. Evidence of toxicity, oxidative stress, and neuronal insult in autism. J Toxicol Environ Health B Crit Rev. 2006; 9: 485-99.

53. Mutter J, Naumann J, Schneider R, Walach H, Haley B. Mercury and autism: accelerating evidence? Neuro Endocrinol Lett. 2005; 26 : 439-46.

54. Geier DA, Kern JK, Garver CR, Adams JB, Audhya T, Nataf R, et al Biomarkers of environmental toxicity and susceptibility in autism. J Neurol Sci. 2009; 280: $101-8$.

55. Nath R. Health and disease Role of micronutrients and trace elements New Delhi: APH Publishing Corporation; 2000.

56. Bornhorst JA, Gwendolyn A, Millin M. Trace and toxic elemental testing in the clinical laboratory. Lab Med 2006; 37: 690-5.

57. Adams JB, Baral M, Geis E, Mitchell J, Ingram J, Hensley A, et al. The severity of autism is associated with toxic metal body burden 
and red blood cell glutathione levels. J Toxicol. 2009; 2009: 532640 . doi: 10.1155/2009/532640.

58. Madsen E, Gitlin JD. Copper and iron disorders of the brain. Annu Rev Neurosci. 2007; 30: 317-37.

59. Werbach MR. Nutritional influences on mental illness. Tarzana, CA: Third Line Press; 1991.

60. Hoffer A. Children with learning and behavioral disorders. J Orthomol Psychiatry. 1976; 5: 228-30.

61. Elson M. Haas. Staying healthy with nutrition, celestial arts. (http:// www.healthy.net/scr/bio.aspx/)

62. Adams J, Holloway C, George F, Quig D. Analyses of toxic metals and essential minerals in the hair of Arizona children with autism and associated conditions, and their mothers. Biol Trace Elem Res. 2006; 110: 193-209.

63. Martineau J, Laffont F, Bruneau N, Roux S, Lelord G. Event related potentials evoked by sensory stimulation in normal, mentally retarded and autistic children. Electroencephalogr Clin Neurophysiol. 1980; 48: 140-53.

64. Watts DL. The nutritional relationships of magnesium. J Orthomol Med. 1988; 3: 197-201.

65. Werbach M. Nutritional influences on aggressive behavior. J Orthomol Med. 1992; 7: 45-51.

66. Passwater RA, Cranton EM. Trace elements: hair analysis and nutrition. New Canaan, CT: Keats Publ; 1983.

67. Marlowe M, Cossairt A, Stellern J. Decreased magnesium in the hair of autistic children. J orthomol psychiatry. 1984; 13: 117-22.

68. Environmental working group [homepage in the Internet]. Environmental Triggers \& New Clues; 2004 [updated 2004 Dec 13; cited 2014 Jan 31]. Available from: http://www.ewg.org/research/ overloaded/environmental-triggers-new-clues.

69. US Food and Drug Administration. [homepage on the Internet]. Tallahassee: Mercury Exposure Levels from Amalgam Dental Fillings; Documentations of Mechanism by Which Mercury Causes over 40 Chronic Health Conditions; Result of Replacement of Amalgam Fillings; and Occupational Effects on Dental Staff by Bernard Windham; 1999. [cited 2014 Oct 4]. Available from: http:// www.fda.gov/ohrms/dockets/dailys/02/Sep02/091602/80027dde. pdf.

70. Autism Research Institute [homepage on the Internet]. San Diego: Autism Treatment Evaluation Checklist (ATEC); 1999 [cited 2014 Nov 25]. Available from: http://www.autism.com/ari.

71. Bernard S, Enayati A, Redwood L, Roger H, Binstock T. Autism: a novel form of mercury poisoning. Med Hypotheses. 2001; 56: 46271.

72. Brockel BJ, Cory-Slechta DA. Lead, attention and impulsive behavior: changes in a fixed-ratio waiting-for-reward paradigm. Pharmacol Biochem Behav. 1998; 60: 545-52.

73. Lakshmi Priya MD, Geetha A. Level of Trace Elements (Copper, Zinc, Magnesium and Selenium) and Toxic Elements (Lead and Mercury) in the Hair and Nail of Children with Autism. Biol Trace Elem Res. 2011; 142: 148-58.

74. Kazi TG, Jalbani N, Kazi N, Jamali MK, Arain MS, Afridi HI, et al. Evaluation of toxic metals in blood and urine samples of chronic renal failure patients, before and after dialysis. Ren Fail. 2008; 30: 737-45.

75. Ayodele JT, Bayero AS. Lead and zinc concentrations in hair and nail of some kano inhabitants. African J Env Sci Tech. 2009; 3: 164-70.

76. Beard JL. Iron biology in immune function, muscle metabolism and neuronal functioning. J Nutr. 2001; 131: 568S-79S.

77. McCann JC, Ames BN. An overview of evidence for a causal relation between iron deficiency during development and deficits in cognitive or behavioral function. Am J Clin Nutr. 2007; 85: 931-45.
78. Erikson KM, Jones BC, Hess EJ, Zhang Q, Beard JL. Iron deficiency decreases dopamine D1 and D2 receptors in rat brain. Pharmacol Biochem Behav. 2001; 69: 409-18.

79. King CR. A novel embryological theory of autism causation involving endogenous biochemicals capable of initiating cellular gene transcription: a possible link between twelve autism risk factors and the autism 'epidemic'. Med Hypotheses. 2011; 76: 653-60.

80. Libbey JE, Sweeten TL, Mcmahon WM, Fujinami RS. Autistic disorder and viral infections. J Neurovirol. 2005; 11: 1-10.

81. Fatemi SH, Earle J, Kanodia R, Kist D, Emamian ES, Patterson PH, et al. Prenatal viral infection leads to pyramidal cell atrophy and macrocephaly in adulthood: implications for genesis of autism and schizophrenia. Cell Mol Neurobiol. 2002; 22: 25-33.

82. Steinman G. Predicting autism at birth. Med Hypotheses. 2013; 81: 21-5.

83. Zikopoulos B, Barbas H. Changes in prefrontal axons may disrupt the network in autism. J Neurosci. 2010; 30: 14595-609.

84. Bondy CA, Lee WH, Cheng CM. Insulin-like growth factor I (IGFI) and brain development. In: LeRoith D, Zumkeller W, Baxter RC, editors. Insulin-like growth factors. New York: Kluwer Academic/ Plenum Publishers; 2003. p.37-157.

85. Koul O. Myelin and autism. In: Bauman M, Kemper TL, editors. The neurobiology of autism. Baltimore: Johns Hopkins Univ Press; 2005. p.150-63.

86. Ye P, Li L, Richards RG, DiAugustine RP, D’Ercole AJ. Myelination is altered in insulin-like growth factor-I null mutant mice. J Neurosci. 2002; 22: 6041-51.

87. Granero-Moltó F, Myers TJ, Weis JA, Longobardi L, Li T, Yan Y, et al. Mesenchymal stem cells expressing insulin-like growth factor-I (MSCIGF) promote fracture healing and restore new bone formation in Irs1 knockout mice: analyses of MSCIGF autocrine and paracrine regenerative effects. Stem Cells. 2011; 29: 1537-48.

88. Herbert MR. Contributions of the environment and environmentally vulnerable physiology to autism spectrum disorders. Curr Opin Neurol. 2010; 23:103-10.

89. Valicenti-McDermott MD, McVicar K, Cohen HJ, Wershil BK, Shinnar S. Gastrointestinal symptoms in children with an autism spectrum disorder and language regression. Pediatr Neurol. 2008; 39: 392-8.

90. Wiest MM, German JB, Harvey DJ, Watkins SM, Hertz-Picciotto I. Plasma fatty acid profiles in autism: a case-control study. Prostaglandins Leukot Essent Fatty Acids. 2009; 80: 221-7.

91. Morris C, Agin MC. Syndrome of allergy, apraxia, and malabsorption: characterization of a neurodevelopmental phenotype that responds to omega 3 and vitamin E supplementation. Altern Ther Health Med. 2009; 15: 34-43.

92. Bent S, Bertoglio K, Hendren RL. Omega-3 fatty acids for autistic spectrum disorder: a systematic review. J Autism Dev Disord. 2009; 39: 1145-54.

93. Dufault R, Schnoll R, Lukiw WJ, Leblanc B, Cornett C, Patrick L, et al. Mercury exposure, nutritional deficiencies and metabolic disruptions may affect learning in children. Behav Brain Funct. 2009; 5: 44. doi: 10.1186/1744-9081-5-44.

94. Herndon AC, DiGuiseppi C, Johnson SL, Leiferman J, Reynolds A. Does nutritional intake differ between children with autism spectrum disorders and children with typical development? J Autism Dev Disord. 2009; 39: 212-22.

95. Persico AM, Napolioni V. Urinary p-cresol in autism spectrum disorder. Neurotoxicol Teratol. 2013; 36: 82-90.

96. Nunomura A, Moreira PI, Lee HG, Zhu X, Castellani RJ, Smith MA, et al. Neuronal death and survival under oxidative stress in Alzheimer and Parkinson diseases. CNS Neurol Disord Drug 
Targets. 2007; 6: 411-23.

97. Gerhardsson L, Blennow K, Lundh T, Londos E, Minthon L. Concentrations of metals, beta-amyloid and tau-markers in cerebrospinal fluid in patients with Alzheimer's disease. Dement Geriatr Cognit Disord. 2009; 28: 88-94.

98. Valko M, Morris H, Cronin MT. Metals, toxicity and oxidative stress. Curr Med Chem. 2005; 12: 1161-208.

99. Deth R, Muratore C, Benzecry J, Power-Charnitsky VA, Waly M. How environmental and genetic factors combine to cause autism: a redox/methylation hypothesis. Neurotoxicology. 2008; 29: 190201.

100. Campagnoni AT. Molecular biology of myelin proteins from the central nervous system. J Neurochem. 1988; 51: 1-14.

101. Rawal N, Lee YJ, Paik WK, Kim S. Studies on NG-methylarginine derivatives in myelin basic protein from developing and mutant mouse brain. Biochem J. 1992; 287: 929-35.

102. Ballatori N, Clarkson TW. Biliary secretion of glutathione and of glutathione-metal complexes. Fundam Appl Toxicol. 1985; 5: 81631 .

103. Ahearn GA, Mandal PK, Mandal A. Mechanisms of heavy metal sequestration and detoxification in crustaceans: a review. J Comp Physiol B. 2004; 174: 439-52.

104. Woods JS. Altered porphyrin metabolism as a biomarker of mercury exposure and toxicity. Can J Physiol Pharmacol. 1996; 74: 210-5.

105. Frustaci A, Neri M, Cesario A, Adams JB, Domenici E, Della Bernardina B, et al. Oxidative stress-related biomarker in autism: systemic review and meta -analysis. Free Rad Biol Med. 2012; 52: 2128-41.

106. Winyard PG, Moody CJ, Jacob C. Oxidative activation of antioxidant defence. Trends Biochem Sci. 2005; 30: 453-61.

107. James SJ, Cutler P, Melnyk S, Jernigan S, Janak L, Gaylor DW, et al. Metabolic biomarkers of increased oxidative stress and impaired methylation capacity in children with autism. Am J Clin Nutr. 2004; 80: 1611-7.

108. Waly M, Olteanu H, Banerjee R, Choi SW, Mason JB, Parker BS, et al. Activation of methionine synthase by insulin-like growth factor-1 and dopamine: a target for neurodevelopmental toxins and thimerosal. Mol Psychiatry. 2004; 9: 358-70.

109. Demiralp T, Herrmann CS, Erdal ME, Ergenoglu T, Keskin YH, Ergen M, et al. DRD4 and DAT1 polymorphisms modulate human gamma band responses. Cereb Cortex. 2007; 17: 1007-19.

110. Deth RC. Molecular origins of attention: the dopamine-folate connection. Amsterdam: Kluwer Academic Publishers; 2003.

111. Faraone SV, Khan SA. Candidate gene studies of attention-deficit/ hyperactivity disorder. J Clin Psychiatry. 2006; 67(Suppl 8): 13-20.

112. LaHoste GJ, Swanson JM, Wigal SB, Glabe C, Wigal T, King N, et al. Dopamine D4 receptor gene polymorphism is associated with attention deficit hyperactivity disorder. Mol Psychiatry. 1996; 1: 121-4.

113. Anderson GM. Genetics of childhood disorders: XLV. Autism, part 4: serotonin in autism. J Am Acad Child Adolesc Psychiatry. 2002; 41: 1513-6.

114. Adams JB, Audhya T, McDonough-Means S, Rubin RA, Quig D, Geis $\mathrm{E}$, et al. Nutritional and metabolic status of children with autism vs. neurotypical children, and the association with autism severity. Nutr Metabol (Lond). 2011; 8: 34. doi: 10.1186/1743-7075-8-34.

115. D’eufemia P, Finocchiaro R, Celli M, Viozzi L, Monteleone D, Giardini O. Low serum tryptophan to large neutral amino acids ratio in idiopathic infantile autism. Biomed Pharmacother. 1995; 49: 28892.

116. Boccuto L, Chen CF, Pittman AR, Skinner CD, McCartney HJ, Jones $\mathrm{K}$, et al. Decreased tryptophan metabolism in patients with autism spectrum disorders. Mol Autism. 2013; 4: 16. doi: 10.1186/20402392-4-16.

117. Stone TW, Darlington LG. Endogenous kynurenines as targets for drug discovery and development. Nat Rev Drug Discov. 2002; 1 : 609-20.

118. Barnes NM, Sharp T. A review of central 5-HT receptors and their function. Neuropharmacology. 1999; 38: 1083-152.

119. Bonnin A, Goeden N, Chen K, Wilson ML, King J, Shih JC, et al. A transient placental source of serotonin for the fetal forebrain. Nature. 2011; 472: 347-50.

120. Schwartz CE. Aberrant tryptophan metabolism: the unifying biochemical basis for autism spectrum disorders? Biomark Med. 2014; 8: 313-5

121. Bock KA. Integrative approach to autism spectrum disorders. In: Rimland B, editor. DAN! (Defeat Autism Now!) Spring 2002 Conference Practitioner Training San Diego, CA: Autism Research Institute; 2002

122. Gupta S. Immunological treatments for autism. J Autism Dev Disord 2000; 30: 475-9.

123. Wakefield AJ, Murch SH, Anthony A, Linnell J, Casson DM, Malik $\mathrm{M}$, et al. Ileal-lymphoid-nodular hyperplasia, non-specific colitis, and pervasive developmental disorder in children. Lancet. 1998; 351: 637-41.

124. Cohly HHP, Panja A. Immunological findings in autism. Int Rev Neurobiol. 2005; 71: 317-41.

125. Ciaranello AL, Ciaranello RD. The neurobiology of infantile autism. Annu Rev Neurosci. 1995; 18: 101-28.

126. Patterson PH. Maternal infection: window on neuroimmune interactions in fetal brain development and mental illness. Curr Opin Neurobiol. 2002; 12: 115-8.

127. Pletnikov MV, Moran TH, Carbone KM. Borna disease virus infection of the neonatal rat: developmental brain injury model of autism spectrum disorders. Front Biosci. 2002; 7: d593-607.

128. Comi AM, Zimmerman AW, Frye VH, Law PA, Peeden JN. Familial clustering of autoimmune disorders and evaluation of medical risk factors in autism. J Child Neurol. 1999; 14: 388-94.

129. Giralt M, Penkowa M, Hernández J, Molinero A, Carrasco J, Lago N, et al. Metallothionein-1+2 deficiency increases brain pathology in transgenic mice with astrocyte-targeted expression of interleukin 6 . Neurobiology Dis. 2002; 9: 319-38.

130. Urakubo A, Jarskog LF, Lieberman JA, Gilmore JH. Prenatal exposure to maternal infection alters cytokine expression in the placenta, amniotic fluid and fetal brain. Schizophrenia Res. 2001; 47: 27-36.

131. Hornig M, Mervis R, HoVman K, Lipkin WI. Infectious and immune factors in neurodevelopmental damage. Mol Psychiatry 2002; 7 (Suppl. 2): S34-5.

132. Goines P, Van de Water J. The immune system's role in the biology of autism. Curr Opin Neurol. 2010; 23: 111-7.

133. Buehler MR. A proposed mechanism for autism: an aberrant neuroimmune response manifested as a psychiatric disorder. Med Hypotheses. 2011; 76: 863-70

134. Pollak Y, Yirmiya R. Cytokine-induced changes in mood and behaviour: implications for 'depression due to a general medical condition', immunotherapy and antidepressive treatment. Int J Neuropscyhopharmacol. 2002; 5: 389-99.

135. Ashwood P, Van de Water. Is autism an autoimmune disease? Autoimmun Rev. 2004; 3: 557-62.

136. Cook EH, Leventhal BL. The serotonin system in autism. Curr Opin Pediatr. 1996; 8: 348-54.

137. Cook EH. Autism: review of neurochemical investigation. Synapse. 1990; 6: 292-308. 
138. Betancur C, Corbex M, Spielewoy C, Philippe A, Laplanche JL, Launay JM, et al. Serotonin transporter gene polymorphisms and hyperserotonemia in autistic disorder. Mol Psychiatry. 2002; 7: 6771.

139. Delneste Y, Herbault N, Galea B, Magistrelli G, Bazin I, Bonnefoy JY, et al. Vasoactive intestinal peptide synergizes with TNF-alpha in inducing human dendritic cell maturation. J Immunol. 1999; 163: 3071-5.

140. Trottier G, Srivastava L, Walker CD. Etiology of infantile autism: a review of recent advances in genetic and neuro- biological research. J Psychiatry Neurosci. 1999; 24: 103-15.

141. van Gent T, Heijnen CJ, Treffers PD. Autism and the immune system. J Child Psychol Psychiatry. 1997; 38: 337-49.

142. Cook Jr EH, Perry BD, Dawson G, Wainwright MS, Leventhal BL. Receptor inhibition by immunoglobulins: specific inhibition by autistic children, their relatives, and control subjects. J Autism Dev Disord. 1993; 23: 67-78.

143. Singh VK, Warren R, Averett R, Ghaziuddin M. Circulating autoantibodies to neuronal and glial filament proteins in autism. Pediatr Neurol. 1997; 17: 88-90.

144. Kozlovskaia GV, Kliushnik TP, Goriunova AV, Turkova IL, Kalinina MA, Sergienko NS. [Nerve growth factor autoantibodies in children with various forms of mental dysontogenesis and in schizophrenia high risk group]. Zh Nevropatol Psihiatr S S Korsakova. 2000; 100: 50-2.

145. Todd RD, Hickok JM, Anderson GM, Cohen DJ. Antibrain antibodies in infantile autism. Biol Psychiatry. 1988; 23: 644-7.

146. Connolly AM, Chez MG, Pestronk A, Arnold ST, Mehta S, Deuel RK. Serum autoantibodies to brain in Landau-Kleffner variant, autism, and other neurologic disorders. J Pediatr. 1999; 134: 607-13.

147. Singh VK, Rivas WH. Prevalence of serum antibodies to caudate nucleus in autistic children. Neurosci Lett. 2004; 355: 53-6.

148. Plioplys AV, Greaves A, Yoshida W. Anti-CNS antibodies in childhood neurologic diseases. Neuropediatrics. 1989; 20: 93-102.

149. Todd RD, Ciaranello RD. Demonstration of inter- and intra-species differences in serotonin binding sites by antibodies from an autistic child. Proc Natl Acad Sci USA. 1985; 82: 612-6.

150. Singh VK, Warren RP, Odell JD, Warren WL, Cole P. Antibodies to myelin basic protein in children with autistic behavior. Brain Behav Immun. 1993; 7: 97-103.

151. Silva SC, Correia C, Fesel C, Barreto M, Coutinho AM, Marques $\mathrm{C}$, et al. Autoantibody repertoires to brain tissue in autism nuclear families. J Neuroimmunol. 2004; 152: 176-82.

152. Careaga M, Van de Water J, Ashwood P. Immune dysfunction in autism: a pathway to treatment. Neurotherapeutics. 2010; 7: 283-92.

153. Onore C, Careaga M, Ashwood P. The role of immune dysfunction in the pathophysiology of autism. Brain Behav Immun. 2012; 26: 383-92.

154. Money J, Bobrow NA, Clarke FC. Autism and autoimmune disease: a family study. J Autism Child Schizophr. 1971; 1: 146-60.

155. Sweeten TL, Bowyer SL, Posey DJ, Halberstadt GM, McDougle CJ. Increased prevalence of familial autoimmunity in probands with pervasive develop- mental disorders. Pediatrics. 2003; 112: e420.

156. Atladóttir HO, Pedersen MG, Thorsen P, Mortensen PB, DeleuranB, Eaton WW, et al. Association of family history of autoimmune diseases and autism spectrum disorders. Pediatrics. 2009; 124: 68794.

157. Molloy CA, Morrow AL, Meinzen-Derr J, Dawson G, Bernier R, Dunn $\mathrm{M}$, et al. Familial autoimmune thyroid disease as a risk factor for regression in children with autism spectrum disorder: a CPEA study. J Autism Dev Disord. 2006; 36: 317-24.

158. Keil A, Daniels JL, Forssen U, Hultman C, Cnattingius S, Söderberg
$\mathrm{KC}$, et al. Parental autoimmune diseases associated with autism spectrum disorders in offspring. Epidemiology. 2010; 21: 805-8.

159. Croen LA, Grether JK, Yoshida CK, Odouli R, Van de Water J. Maternal autoimmune diseases, asthma and allergies, and childhood autism spec- trum disorders: a case-control study. Arch Pediatr Adolesc Med. 2005; 159: 151-7.

160. Gesundheit B, Rosensweig JP, Naor D, Lerer B, Zachor DA, Procházka $\mathrm{V}$, et al. Immunological and autoimmune considerations of Autism Spectrum Disorders. J Autoimmun. 2013; 44: 1-7.

161. Williams BL, Hornig M, Buie T, Bauman ML, Paik MC, Wick I, et al. Impaired carbohydrate digestion and transport and mucosal dysbiosis in the intestines of children with autism and gastrointestinal disturbances. PloS One. 2011; 6: e24585. doi: 10.1371/journal.pone.0024585

162. D'Eufemia P, Celli M, Finocchiaro R, Pacifico L, Viozzi L, Zaccagnini $\mathrm{M}$, et al. Abnormal intestinal permeability in children with autism. Acta Paediatr. 1996; 85: 1076-9.

163. Horvath K, Papadimitriou JC, Rabsztyn A, Drachenberg C, Tildon JT Gastrointestinal abnormalities in children with autistic disorder. J Pediatr. 1999; 135: 559-63.

164. Finegold SM, Molitoris D, Song Y, Liu C, Vaisanen ML, Bolte E, et al. Gastrointestinal microflora studies in late-onset autism. Clin Infect Dis. 2002; 35: S6-16.

165. Song Y, Liu C, Finegold SM. Real-time PCR quantitation of clostridia in feces of autistic children. Appl Environ Microbiol. 2004; 70: 6459-65.

166. Parracho HM, Bingham MO, Gibson GR, McCartney AL. Differences between the gut microflora of children with autistic spectrum disorders and that of healthy children. J Med Microbiol. 2005; 54: 987-91.

167. Knivsberg AM, Reichelt KL, Hoien T, Nodland M. A randomised, controlled study of dietary intervention in autistic syndromes. Nutr Neurosci. 2002; 5: 251-61.

168. Sandler RH, Finegold SM, Bolte ER, Buchanan CP, Maxwell AP, Väisänen ML, et al. Short-term benefit from oral vancomycin treatment of regressive-onset autism. J Child Neurol. 2000; 15: 42935 .

169. Adams JB, Johansen LJ, Powell LD, Quig D, Rubin RA. Gastrointestinal flora and gastrointestinal status in children with autism-comparisons to typical children and correlation with autism severity. BMC Gastroenterol. 2011; 11: 22.

170. Cryan JF, O'Mahony SM. The mocrobiome-gut-brain axis: from bowel to behavior. Neurogastroenterol Motil. 2011; 23: 187-92.

171. Hallmayer J, Cleveland S, Torres A, Phillips J, Cohen B, Torigoe T, et al. Genetic heritability and shared environmental factors among twin pairs with autism. Arch Gen Psychiatry. 2011; 68: 1095-102.

172. Lucarelli S, Frediani T, Zingoni AM, Ferruzzi F, Giardini O, Quintieri F, et al. Food allergy and infantile autism. Panminerva Med. 1995; 37: 137-41.

173. Van Oudenhove L, Demyttenaere K, Tack J, Aziz Q. Central nervous system involvement in functional gastrointestinal disorders. Best Pract Res Clin Gastroenterol. 2004; 18: 663-80.

174. Altaf MA, Sood MR. The nervous system and gastrointestinal function. Dev Disabil Res Rev. 2008; 14: 87-95.

175. Sullivan PB. Gastrointestinal disorders in children with neurodevelopmental disabilities. Dev Disabil Res Rev. 2008; 14: 128-36.

176. Drossman DA, Creed FH, Olden KW, Svedlund J, Toner BB, Whitehead WE. Psychosocial aspects of the functional gastrointestinal disorders. Gut. 1999; 45 (Suppl. 2): II25-30.

177. Larsen N, Vogensen FK, van den Berg FW, Nielsen DS, Andreasen AS, Pedersen BK, et al. Gut microbiota in human adults with type 
2 diabetes differs from nondiabetic adults. PLoS ONE. 2010; 5: e9085. doi: 10.1371/journal.pone.0009085.

178. Arumugam M, Raes J, Pelletier E, Le Paslier D, Yamada T, Mende DR, et al. Enterotypes of the human gut microbiome. Nature. 2011; 473: $174-80$.

179. Wu GD, Chen J, Hoffmann C, Bittinger K, Chen YY, Keilbaugh $\mathrm{SA}$, et al. Linking longterm dietary patterns with gut microbial enterotypes. Science. 2011; 334: 105-8.

180. Huse SM, Ye Y, Zhou Y, Fodor AA. A core human microbiome as viewed through 16S rRNA sequence clusters. PLoS ONE. 2012; 7: e34242. doi: 10.1371/journal.pone.0034242.

181. McKay DM. Intestinal inflammation and the gut microflora. Can J Gastroenterol. 1999; 13: 509-16.

182. Bjarnason I, Macpherson A, Hollander D. Intestinal permeability: an overview. Gastroenterology. 1995; 108: 1566-81.

183. Garvey J. Diet in autism and associated disorders. J Fam Health Care. 2002; 12: 34-8.

184. Wang L, Conlon MA, Christophersen CT, Sorich MJ, Angley MT. Gastrointestinal microbiota and metabolite biomarkers in children with autism spectrum disorders. Biomark Med. 2014; 8: 331-44.

185. Cummings JH, MacFarlane GT. The control and consequences of bacterial fermentation in the human colon. J Appl Bacteriol. 1991; 70: 443-59.

186. Wang L, Angley MT, Gerber JP, Sorich MJ. A review of candidate urinary biomarkers for autism spectrum disorder. Biomarkers. 2011; 16: 537-52.

187. El-Ansary AK, Ben Bacha A, Kotb M. Etiology of autistic features: the persisting neurotoxic effects of propionic acid. J Neuroinflammation. 2012; 9: 74. doi: 10.1186/1742-2094-9-74.

188. MacFabe DF. Shortchain fatty acid fermentation products of the gut microbiome: implications in autism spectrum disorders. Microb Ecol Health Dis. 2012; 23. doi: 10.3402/mehd.v23i0.19260.

189. AlLahham SH, Peppelenbosch MP, Roelofsen H, Vonk RJ, Venema $\mathrm{K}$. Biological effects of propionic acid in humans; metabolism, potential applications and underlying mechanisms. Biochim Biophys Acta. 2010; 1801: 1175-83.

190. Shultz SR, MacFabe DF, Martin S, Jackson J, Taylor R, Boon F, et al. Intracerebroventricular injections of the enteric bacterial metabolic product propionic acid impair cognition and sensorimotor ability in the Long-Evans rat: further development of a rodent model of autism. Behav Brain Res. 2009; 200: 33-4.

191. MacFabe DF, RodraguezCapote K, Hoffman JE, Franklin AE, Mohammad-Asef Y, Taylor AR, et al. A novel rodent model of autism: Intraventricular infusions of propionic acid increase locomotor activity and induce neuroinflammation and oxidative stress in discrete regions of adult rat brain. Am J Biochem Biotechnol. 2008; 4: 146-66.

192. Tjellström B, Stenhammar L, Högberg L, Fälth-Magnusson K, Magnusson KE, Midtvedt $\mathrm{T}$, et al. Gut microflora associated characteristics in children with celiac disease. Am J Gastroenterol. 2005; 100: 2784-8.

193. Kau AL, Ahern PP, Griffin NW, Goodman AL, Gordon JI. Human nutrition, the gut microbiome and the immune system. Nature. 2011; 474: 327-36.

194. Maslowski KM, Vieira AT, Ng A, Kranich J, Kranich J, Sierro F, et al. Regulation of inflammatory responses by gut microbiota and chemoattractant receptor GPR43. Nature. 2009; 461: 1282-6.

195. de Magistris L, Familiari V, Pascotto A, Sapone A, Frolli A, Iardino $\mathrm{P}$, et al. Alterations of the intestinal barrier in patients with autism spectrum disorders and in their first-degree relatives. J Pediatr Gastr Nutr. 2010; 51: 418-24.

196. Wang L, Christophersen CT, Sorich MJ, Gerber JP, Angley MT,
Conlon MA. Elevated Fecal Short Chain Fatty Acid and Ammonia Concentrations in Children with Autism Spectrum Disorder. Dig Dis Sci. 2012; 57: 2096-102.

197. Ramakrishna BS, Gee D, Weiss A, Pannall P, RobertsThomson IC, Roediger WE. Estimation of phenolic conjugation by colonic mucosa. J Clin Pathol. 1989; 42: 620-3.

198. Altieri L, Neri C, Sacco R, Curatolo P, Benvenuto A, Muratori F, et al. Urinary pcresol is elevated in small children with severe autism spectrum disorder. Biomarkers. 2011; 16: 252-60.

199. Hsiao EY, MxBride SW, Hsien S, Hyde ER, Sharon J, McGue T, et al. Microbiota modulate behavioral and physiological abnormalities associated with neurodevelopmental disorders. Cell. 2013; 155: 1451-63.

200. Mizejewsky G. Biomarker testing for suspected autism spectrum disorder in early childhood: is such testing now feasible? Biomarkers Med. 2012; 6: 503-6.

201. Steinman G, Mankuta D. Insulin-like growth factor and the etiology of autism. Med Hypotheses. 2013; 80: 475-80.

202. Arends N, Johnston L, Hokken-Koelega A, van Duijn C, de Ridder $\mathrm{M}$, Savage M, et al. Polymorphism in the IGF-I gene: clinical relevance for short children born small for gestational age (SGA). J Clin Endocrinol Metab. 2002; 87: 2720-4.

203. Blanco CL, Ferry RJ. Jr. The insulin-like growth factor axis in the fetus and neonate. In: Houston MS, Holly NMP, Feldman EL, editors. IGF and Nutrition in Health and Disease. Totowa, NJ: Humana Press; 2005. p.33-143.

204. Durkin MS, Maenner MJ, Newschaffer CJ, Lee LC, Cunniff CM, Daniels JL, et al. Advanced parental age and the risk of autism spectrum disorder. Am J Epidemiol. 2008; 168: 1268-76.

205. Patterson PH. Maternal infection and immune involvement in autism. Trends Mol Med. 2011; 17: 389-94.

206. Geschwind DH. Genetics of autism spectrum disorder. Trends Cogn Sci. 2011; 15: 409-16.

207. Hsiao EY, Patterson PH. Activation of the maternal immune system induces endocrine changes in the placenta via IL-6. Brain Behav Immun. 2010; 25: 604-15.

208. Infectious Disease. In: Benirschke K, Kaufmann P. Pathology of the human placenta. 4th ed. New York: Springer-Verlag; 2000. p.591608.

209. Meyer U, Yee BK, Feldon J. The neurodevelopmental impact of prenatal infections at different times of pregnancy: the earlier the worse? Neuroscientist. 2007; 13: 241-56.

210. Wei H, Zou H, Sheikh AM, Malik M, Dobkin C, Brown WT, et al. IL-6 is increased in the cerebellum of autistic brain and alters neural cell adhesion migration and synaptic formation. J Neuroinflam. 2011; 18: 52. doi: 10.1186/1742-2094-8-52.

211. Dammann O, Leviton A. Maternal intrauterine infection, cytokines, and brain damage in the preterm newborn. Pediatr Res. 1997; 42: $1-8$.

212. Morell P, Quarles RH. Myelin formation, structure, and biochemistry in basic neurochemistry. In: Siegel G, editor. Proceedings of Studies. Philadelphia: Lippincott Williams \& Wilkins; 1999. p.81-92.

213. Mattson MP, Maudsley S, Martin B. A neural signaling triumvirate that influences ageing and age-related disease: insulin/IGF-1. BDNF and serotonin. Ageing Res Rev. 2004; 3: 445-64.

214. Mostafa GA, Al-Ayadhi LY. A lack of association between hyperserotonemia and the increased frequency of serum antimyelin basic protein auto- antibodies in autistic children. J Neuroinflammation. 2011; 8: 71. doi: 10.1186/1742-2094-8-71.

215. Leboyer M, Philippe A, Bouvard M, Guilloud-Bataille M, Bondoux $\mathrm{D}$, Tabuteau $\mathrm{F}$, et al. Whole blood serotonin and plasma betaendorphin in autistic probands and their first-degree relatives. Biol 
Psychiatry. 1999; 45: 158-63.

216. Whitaker-Azmitia PM. Serotonin and brain development: role in human developmental diseases. Brain Res Bull. 2001; 56: 479-85.

217. Mansour M, Mohamed A, Azam H, Henedy M. Brain derived neurotrophic factor in autism. Current Psychiatry. 2010; 17: 23-8.

218. Yirmiya N, Pilowsky T, Nemanov L, Arbelle S, Feinsilver T, Fried $\mathrm{I}$, et al. Evidence for an association with the serotonin transporter promoter region polymorphism and autism. A J Med Genet. 2001; 105: 381-6.

219. Schain RJ, Freeman BJ. Studies on 5-hydroxyindole metabolism in autistic and other mentally retarded children. J Pediatr. 1961; 58: 315-20.

220. Veenstra-VanderWeele J, Muller CL, Iwamoto H, Sauer JE, Owens WA, Shah CR, et al. Autism gene variant causes hyperserotonemia, serotonin receptor hypersensitivity, social impairment and repetitive behavior. Proc Natl Acad Sci USA. 2012; 109: 5469-74.

221. Angelidou A, Francis K, Vasiadi M, Alysandratos KD, Zhang B, Theoharides A, et al. Neurotensin is increased in serum of young children with autistic disorders. J Neuroinflammation. 2010; 7: 48. doi: 10.1186/1742-2094-7-48.

222. Persico AM. Autisms. In: Comprehensive Developmental Neuroscience, Rakic P and Rubenstein J, editors. San Diego: Elsevier; 2013.

223. Wang L, Christophersen CT, Sorich MJ, Gerber JP, Angley MT, Conlon MA. Low relative abundances of the mucolytic bacterium Akkermansia muciniphila and Bifidobacterium spp. in feces of children with autism. Appl Environ Microbiol. 2011; 77: 6718-21.

224. Veenstra-VanderWeele J, Blakely RD. Networking in autism: leveraging genetic, biomarker and model system findings in the search for new treatments. Neuropsychopharmacology. 2012; 37 : 196-212.

225. Walsh P, Elsabbagh M, Bolton P, Singh I. In search of biomarkers for autism: scientific, social and ethical challenges. Nat Rev Neurosci. 2011; 12: 603-12.

226. Frye RE, James SJ. Metabolic pathology of autism in relation to redox metabolism. Biomark Med. 2014; 8: 321-30.

227. Mizejewsky GJ, Lindau-shepard B, Pass KA. Newborn screening for autism: in search of candidate biomarkers. Biomark Med. 2013; 7 : 247-60. 